Chicago-Kent College of Law

Scholarly Commons @ IIT Chicago-Kent College of Law

January 2009

\title{
Guns and Speech Technologies: How the Right to Bear Arms Affects Copyright Regulations of Speech Technologies
}

\author{
Edward Lee \\ IIT Chicago-Kent College of Law, elee@kentlaw.iit.edu
}

Follow this and additional works at: https://scholarship.kentlaw.iit.edu/fac_schol

Part of the Intellectual Property Law Commons

\section{Recommended Citation}

Edward Lee, Guns and Speech Technologies: How the Right to Bear Arms Affects Copyright Regulations of Speech Technologies, 17 Wm. \& Mary Bill Rts. J. 1037 (2009).

Available at: https://scholarship.kentlaw.iit.edu/fac_schol/354

This Article is brought to you for free and open access by the Faculty Scholarship at Scholarly Commons @ IIT Chicago-Kent College of Law. It has been accepted for inclusion in All Faculty Scholarship by an authorized administrator of Scholarly Commons @ IIT Chicago-Kent College of Law. For more information, please contact jwenger@kentlaw.iit.edu, ebarney@kentlaw.iit.edu. 


\section{William \& Mary Bill of Rights Journal}

\section{Guns and Speech Technologies: How the Right to Bear Arms Affects Copyright Regulations of Speech Technologies}

Edward Lee

Repository Citation

Edward Lee, Guns and Speech Technologies: How the Right to Bear Arms Affects Copyright Regulations of Speech Technologies, 17 Wm. \& Mary Bill of Rts. J. 1037 (2009), http://scholarship.law.wm.edu/ wmborj/vol17/iss $4 / 3$

Copyright c 2009 by the authors. This article is brought to you by the William \& Mary Law School Scholarship Repository. http://scholarship.law.wm.edu/wmborj 


\title{
GUNS AND SPEECH TECHNOLOGIES: HOW THE RIGHT TO BEAR ARMS AFFECTS COPYRIGHT REGULATIONS OF SPEECH TECHNOLOGIES
}

\author{
Edward Lee*
}

\section{ABSTRACT}

This Article examines the possible effect the Supreme Court's landmark Second Amendment ruling in District of Columbia v. Heller will have on future cases brought under the Free Press Clause. ${ }^{1}$ Based on the text and history of the Constitution, the connection between the two Clauses is undeniable, as the Heller Court itself repeatedly suggested. Only two provisions in the entire Constitution protect individual rights to a technology: the Second Amendment's right to bear "arms" and the Free Press Clause's right to the freedom of the "press," meaning the printing press. Both rights were viewed, moreover, as pre-existing, natural rights to the Framing generation and were separately called during the Framing the "palladium of liberty" and essential to "the security of freedom in a state." The development of both concepts traces back to the abuses of the Crown in disarming the populace and restricting the printing press in England. During the seventeenth century, the people in England were deprived of both technologies - in the case of the printing press, by the copyright holders of the period known as the Stationers' Company, which conducted warrantless searches to seize unauthorized presses with the backing of the Crown. The Bill of Rights was enacted to stop these abuses in the new Republic. Both clauses developed in direct reaction to the perceived threat of government restrictions on the respective technologies. Given this historical connection, the analysis of the Second Amendment in Heller may provide a useful point of reference for the Court in future cases interpreting the Free Press Clause. Just as Heller held that banning handguns for the purpose of gun control violates the Second Amendment's core protection of the right to possess arms for self-defense, banning speech technologies for the purpose of copyright control violates the Free Press Clause's core protection of speech technologies for self-expression.

* Associate Professor of Law, The Ohio State University Moritz College of Law. Many thanks to David Goldberger, Peter Shane, Marc Spindelman, and Peter Swire for their comments on earlier drafts. I also appreciate the help of Doug Berman, Joshua Dressler, and Alan Michaels in discussing aspects of this Article. Tamara Maynard provided excellent research assistance; Katherine Hall, invaluable reference support from the Michael E. Moritz Law Library.

1 128 S. Ct. 2783 (2008). 


\section{INTRODUCTION}

In District of Columbia v. Heller, the Supreme Court defined, for the first time in 217 years of the Second Amendment's existence, an individual right to keep and bear arms for self-defense purposes. ${ }^{2}$ This landmark decision settled, once and for all, the lingering question of whether the Second Amendment recognizes a general right to bear arms for all individuals, or instead limits such right only to the context of a militia. In a 5-4 decision, the Court opted for the broader interpretation and struck down D.C.'s gun control law that barred individuals from owning handguns in D.C. ${ }^{3}$

The Heller decision will likely have ramifications that are far-reaching. ${ }^{4} \mathrm{~A}$ day after the Heller decision, the National Rifle Association (NRA) filed five different lawsuits against gun control laws in San Francisco, Chicago, and three Chicago suburbs, to extend the Court's ruling to the states through the doctrine of incorporation and to test the constitutionality of other gun control laws. ${ }^{5}$ Only a month later, Dick Heller, the same plaintiff in the Second Amendment lawsuit, filed a constitutional

2128 S. Ct. 2783, 2821 (2008).

${ }^{3}$ Id. at 2821-22.

4 See Cass R. Sunstein, Second Amendment Minimalism: Heller as Griswold, 122 HARV. L. REv. 246, 249 (2008) (" $[\mathrm{I}] \mathrm{t}$ is stunning to see that Heller is a thoroughly originalist opinion- a significant development, and one that is at least potentially important for the future, certainly of the Second Amendment, and perhaps more generally.").

${ }^{5}$ Press Release, Nat'1 Rifle Ass'n Inst. for Legislative Action, NRA Files Second Amendment Lawsuits in Illinois and California Following Supreme Court Ruling (June 27, 2008), available at http://www.nraila.org/Legislation/Read.aspx?ID=4053; see Complaint, NRA v. City of Chicago, No. 08-cv-3697 (N.D. Ill. June 27, 2008), available at http://www .nraila.org/media/PDFs/chicago.pdf; Complaint, NRA v. Village of Oak Park, No. 08-cv3696 (N.D. Ill. June 27, 2008), available at http://www.nraila.org/media/PDFs/oakpark.pdf; Complaint, NRA v. Village of Morton Grove, No. 08-cv-3694 (N.D. Ill. June 27, 2008), available at http://www.nraila.org/media/PDFs/morton.pdf. The District Court for the Northern District of Illinois, feeling bound by prior Seventh Circuit precedent, ruled that the Second Amendment did not apply against the states because it was not incorporated under the Fourteenth Amendment. NRA v. Village of Oak Park, Nos. 08-C-3696, 08-C-3697, 2008 WL 5111163 , at *2 (N.D. Ill. Dec. 4, 2008) (citing Quilici v. Village of Morton Grove, 695 F.2d 261, 269 (7th Cir. 1982)), appeal docketed, Nos. 08-4241, 08-4243, 08-4244 (7th Cir. Dec. 5,2008 ). The Heller Court itself avoided reviewing the "continuity validity" of its 1875 precedent Cruikshank, which held that the Second Amendment was not incorporated. See Heller, 128 S. Ct. at 2813 \& n.23 (discussing United States v. Cruikshank, 92 U.S. 542, 553 (1875)).

On Nov. 4, 2008, the NRA filed a Second Amendment challenge to a Washington state law that requires aliens to obtain a special firearm license, even though the state agency refuses to grant such licenses to aliens. Paul Shukovsky, Washington Sued Over Firearm License Law, SEATTLE POST-INTELLIGENCER, Nov. 4, 2008, at B3, available at http://seattlepi.nwsource .com/local/386392_guns05.html.

The San Francisco Housing Authority settled the case against it and repealed a regulation forbidding individuals in public housing from possessing a gun. See NRA Settles San Francisco Housing Authority Gun Ban Lawsuit, http://www.nraila.org/legislation/read.aspx ?id=4305 (last visited Apr. 21, 2009). 
challenge to D.C.'s newly revised gun control law that banned semiautomatic handguns capable of shooting more than twelve shots without manual reloading. ${ }^{6}$ The Heller Court itself recognized that future litigation may arise to test permissible exceptions to the Second Amendment right, which the Court concluded "is not unlimited."7 As the Court emphasized,

[N]othing in [its] opinion should be taken to cast doubt on longstanding prohibitions on the possession of firearms by felons and the mentally ill, or laws forbidding the carrying of firearms in sensitive places such as schools and government buildings, or laws imposing conditions and qualifications on the commercial sale of arms. ${ }^{8}$

That admonition did nothing to deter subsequent Second Amendment challenges to laws forbidding gun ownership by those convicted of felonies ${ }^{9}$ or misdemeanor crimes of domestic violence. ${ }^{10}$ Although virtually all of these challenges have been rejected thus far, the stream of cases with similar challenges continues unabated. ${ }^{11}$

6 See Posting of Lyle Denniston, to SCOTUSblog, http://www.scotusblog.com/wp/newsecond-amendment-case-in-dc/ (July 28, 2008, 5:31 EST).

7 Heller, 128 S. Ct. at 2816.

${ }^{8}$ Id. at 2816-17.

9 See, e.g., Range v. Indiana, No. 3:08-CV-435 (JVB), 2008 WL 4852679 (N.D. Ind. Nov, 6, 2008); United States v. Lippman, No. 4:02-cr-082, 2008 WL 4661514 (D.N.D. Oct. 20, 2008); United States v. Borgo, No. 1:08-CR-81, 2008 WL 4631422 (W.D.N.C. Oct. 17, 2008); United States v. Whisnant, No. 3:07-CR-32, 2008 WL 4500118 (E.D. Tenn. Sept. 30, 2008); United States v. White, No. 07-00361-WS, 2008 WL 3211298 (S.D. Ala. Aug. 6, 2008); United States v. Robinson, No. 07-CR-202, 2008 WL 2937742 (E.D. Wis. July 23, 2008); see also United States v. Guerrero-Leco, No. 3:08-CR-118, 2008 WL 4534226 (W.D.N.C. Oct. 6, 2008) (rejecting a Second Amendment challenge to a federal law prohibiting illegal alien from possessing firearms); United States v. Yancey, No. 08-cr-103-bbl, 2008 WL 4534201 (W.D. Wis. Oct. 3, 2008) (rejecting a Second Amendment challenge to a federal law prohibiting unlawful user of a controlled substance from possessing firearms).

${ }^{10}$ United States v. Booker, 570 F. Supp. 2d 161, 163-64 (D. Me. 2008).

11 See, e.g., United States v. Fincher, 538 F.3d 868, 874 (8th Cir. 2008) ("Machine guns are not in common use by law-abiding citizens for lawful purposes and therefore fall within the category of dangerous and unusual weapons that the government can prohibit for individual use."); United States v. Luedtke, 589 F. Supp. 2d 1018 (E.D. Wis. 2008) (rejecting a challenge to a federal law banning possessing firearms while under a domestic violence restraining order); United States v. Potter, No. CR07-5683RBL, 2008 WL 4779744 (W.D. Wash. Oct. 31, 2008) (rejecting a challenge to the crime of possessing firearm in furtherance of drug trafficking).

A few challenges have been successful in the context of bail conditions. Two district courts have held facially unconstitutional under the Due Process Clause a provision of the Adam Walsh Act that requires that, "as a condition of release on bail, an accused person [who is charged with possessing child pornography] be required to surrender his Second Amendment right to possess a firearm without giving that person an opportunity to contest 
While Heller no doubt changes the landscape of gun control laws, the most farreaching effect the decision may have is-hard to imagine-in the area of copyright law. Yes, copyright law. My suggestion may seem baffling to many legal scholars at first, but a close analysis of the history of the Second Amendment and of the Free Press Clause, as well as the Court's own discussion in Heller, establishes a close connection between the two. Indeed, of all the provisions in the Constitution, the Framers included only two specifically to protect technologies by name: "arms" in the Second Amendment and the "press," referring to the printing press in the First Amendment's Free Press Clause, which was added to the Constitution to prevent, in part, Congress from exercising its Copyright Clause power in a way that restricted the printing press. ${ }^{12}$ Remarkably, only two technologies were considered so essential to liberty to merit express, constitutional protection during the founding of the Republic: guns and speech technologies.

This Article explains how the Heller decision may call into serious question Congress's ongoing attempts to regulate speech technologies under copyright law. To date, the Court has not had occasion to review the constitutionality of a copyright restriction on a speech technology under the Free Press Clause, so the case law in this area stands very much as the case law regarding the Second Amendment did preHeller: underdeveloped. But as Congress contemplates imposing even further restrictions on speech technologies through copyright law in our digital age, the Court will almost certainly have to consider a free press challenge to such a restriction in

whether such a condition is reasonably necessary in his case to secure the safety of the community." United States v. Arzberger, 592 F. Supp. 2d 590, 603 (S.D.N.Y. 2008); see United States v. Kennedy, 593 F. Supp. 2d 1221 (W.D. Wash. 2008). These cases turned on the infringement of the defendant's Second Amendment right without procedural due process.

A few cases have recognized the Second Amendment right as offering some potential protection in the particular context of the legal dispute. See, e.g., Lund v. Salt Lake City Corp., No. 2:07-CV-0226BSJ, 2008 WL 5119875, at *7 n.9 (D. Utah Dec. 4, 2008) ("By itself, mere possession of a firearm in public is not unlawful and may well represent the exercise of a fundamental constitutional right guaranteed by the Second Amendment to the United States Constitution and Article $I, \S 6$ of the Utah Constitution (recognizing the 'individual right of the people to keep and bear arms for security and defense of self, family, others, property, or the state, as well as for other lawful purposes,' subject to the power of the Legislature to define the 'lawful use of arms.')."); Jennings v. Mukasey, No. 6:08-cv-833-Orl-31GJK, 2008 WL 4371348 , at *2 (M.D. Fla. Sept. 22, 2008) (recognizing a viable Second Amendment claim with respect to application of federal prohibition on possession of firearms by a person convicted of misdemeanor domestic violence crime that was later expunged); United States v. Kitsch, No. 03-594-01, 2008 WL 2971548, at *7 (E.D. Pa. Aug. 1, 2008) ("A statute that imposes criminal penalties for the exercise of an enumerated constitutional right despite defendant's reasonable belief in good faith that he has complied with the law must, at the very least, raise constitutional doubts. Post-Heller, the Government's desired construction of Section 922(g)(1) imposes just such a burden on defendants who, for whatever reason, reasonably believe that they are not felons within the statutory definition.").

12 U.S. CONST. amends. I \& II. 
the near future. And if the Court interprets the Free Press Clause in a manner parallel to the way it has interpreted the Second Amendment-as the Court itself suggested in Heller-Congress's attempts to restrict or ban speech technologies under copyright law will very likely be deemed unconstitutional. Just as bans on guns that serve the purpose of self-defense violate the Second Amendment, bans on technologies that serve the purpose of self-expression violate the First Amendment's Free Press Clause.

Part I provides a brief summary of the Heller decision and its interpretive method, which defined the "core protection" of the Second Amendment from an originalist or historical point of view at the time of the Framing. Part II explains the textual and historical connection between the Second Amendment and the Free Press Clause, the only two clauses in the Constitution that protect an individual right to a technology. The histories followed a remarkably similar path in reaction to the abuses of the Crown in restricting both arms and printing presses in England. Indeed, the core abuse in both cases was the Crown's depriving the people of the technology itself. Part III explains why Heller can provide a helpful point of reference for the Court in reviewing the constitutionality of restrictions on speech technologies under the Free Press Clause. Part IV concludes by examining several copyright restrictions on speech technologies under the Free Press Clause, as interpreted under a "core protection" framework analogous to Heller. The Article suggests that the Audio Home Recording Act of 1992 (AHRA) and Congress's proposed "broadcast flag" bill both violate a core protection of the Free Press Clause, while the anti-circumvention provision of the Digital Millennium Copyright Act of 1998 (DMCA) probably does not.

\section{HISTORY AND HELLER: SELF-DEFENSE AND THE DEVELOPMENT OF THE RIGHT TO KEEP AND BEAR ARMS}

Before drawing the historical connection between the Second Amendment and the Free Press Clause, it is important to spend a few moments on the lengthy Heller decision itself. Justice Scalia wrote the majority opinion, holding that individuals have a Second Amendment right to bear arms for the core purpose of self-defense. ${ }^{13}$ Justice Stevens and Justice Breyer both wrote dissents, concluding that the Second Amendment right was limited to maintaining a "well-regulated militia."14 Breyer also proposed an "interest balancing" test for the Second Amendment. ${ }^{15}$ Although the majority and dissent reached different interpretations, their methods for interpreting the Second Amendment (apart from Breyer's discussion of interest balancing) were fairly similar at least in one important respect-both examined Framing-era historical sources to determine what the words in the Second Amendment originally meant at the time of the Framing or to the Framers. Although scholars can dispute how

13 Heller, $128 \mathrm{~S}$. Ct. at 2817-18.

14 Id. at 2822 (Stevens, J., dissenting); id. at 2847 (Breyer, J., dissenting).

15 Id. at 2852 (Breyer, J., dissenting). 
"originalist" Heller really was, the main arguments of the majority and, even to a large degree, the dissent were fixated on determining the history and original meaning of the Second Amendment. ${ }^{16}$

\section{A. Justice Scalia's Majority Opinion}

Justice Scalia began with a close textual analysis of the words and structure of the Second Amendment and attempted to discern its original meaning at the time of the Framing: "In interpreting this text, we are guided by the principle that ' $[t]$ he Constitution was written to be understood by the voters; its words and phrases were used in their normal and ordinary as distinguished from technical meaning." "17

The majority examined a variety of textual and historical elements to support its analysis, including: (1) the relationship between the operative clause ("the right of the people to keep and bear Arms, shall not be infringed"), which the majority found to be controlling, and the prefatory clause in the Second Amendment ("A well regulated Militia, being necessary to the security of a free State"), which the majority interpreted to be a nonlimiting statement of a purpose of the Amendment; ${ }^{18}(2)$ references to "the people" in other parts of the Constitution as used to define an individual right; 19 (3) contemporaneous dictionary definitions of "keep," "bear," and "arms" suggesting that such terms - either individually or collectively - were not limited to the context of state militias; ${ }^{20}(4)$ historical legal commentaries, such as Blackstone, using such terms; $;^{21}(5)$ state constitutions at the time of the founding, ${ }^{22}$ and (6) the historical background of the right to bear arms for self-defense tracing back to England. ${ }^{23}$

The majority doubted the value of Justice Stevens's reliance "on the drafting history of the Second Amendment - the various proposals in the state conventions and the debates in Congress." 24 In the majority's view, "[i]t is dubious to rely on such history to interpret a text that was widely understood to codify a pre-existing right, rather than to fashion a new one." 25 Why the codification of a pre-existing right versus a new right makes somehow "dubious" a court's consideration of the legislative

16 Sunstein, supra note 4, at 250 ("Justice Scalia's thoroughly originalist opinion commanded a majority of the Court, and Justice Scalia's distinctive brand of originalism, involving the original public meaning, was clearly ascendant. Indeed, the dissenters, spoke in largely originalist terms as well, although Justice Breyer's plea for balancing had pragmatic as well as originalist elements.").

17 Heller, 128 S. Ct. at 2788 (quoting United States v. Sprague, 282 U.S. 716, 731 (1931)).

18 Id. at 2789-2800.

19 Id. at 2790 \& nn.5-6.

${ }^{20}$ Id. at 2791-97.

${ }^{21}$ Id. at 2792, 2798.

${ }^{22}$ Id. at 2793-94.

${ }^{23}$ Id. at 2797-99.

${ }^{24}$ Id. at 2804.

25

Id. 
history of a constitutional amendment, Justice Scalia did not say. For example, even if a right was pre-existing, the comments of the Framers, First Congress, and/or state ratifiers could provide confirmation of the "pre-existing" nature of the right as perceived by those who drafted or ratified the Second Amendment. In any event, the majority assumed that such legislative history was relevant, but concluded that it did not support the dissent's view. ${ }^{26}$ And, as discussed in Part II below, Justice Scalia made extensive use of the historical debate between the Anti-Federalists and the Federalists during the ratification of the Constitution to support the majority's interpretation.

After analyzing the history of the Second Amendment, Scalia concluded that the "core protection" of the Amendment is to protect the individual's right to bear and keep arms for the "core lawful purpose of self-defense." 27

\section{B. Justice Stevens's Dissent}

Justice Stevens wrote the primary opinion for the four dissenting justices on the meaning of the Second Amendment. ${ }^{28}$ Although not known as an originalist as Justice Scalia is, Stevens also relied heavily on the text and historical materials to discern the original understanding of the Second Amendment. But, in contrast with Justice Scalia's search for the "original public meaning" of the text at the time of the Framing (sometimes called the "New Originalism" or "public meaning originalism"), ${ }^{29}$ Justice Stevens searched for the "Framers' intent" or purpose in enacting the Amendment. ${ }^{30}$ Justice Stevens also made greater use of the legislative history of the Second Amendment, including various state proposals and the debates in Congress. ${ }^{31}$ This legislative history was secondary, however, to Stevens's primary argument that the

26 Id.

27 Id. at $2818,2821$.

28 Id. at 2822 (Stevens, J., dissenting).

29 See Randy E. BARNetT, Restoring the Lost CONSTITUTION: THE PRESUMPTION OF LIBERTY 92-93 (2004) (distinguishing original meaning versus original intent); Gary Lawson \& Guy Seidman, Originalism as a Legal Enterprise, 23 CONST. COMMENT. 47, 48 (2006) ("The reasonable American person of 1788 determines, for 1788 and today, the meaning of the federal Constitution. Thus, when interpreting the Constitution, the touchstone is not the specific thoughts in the heads of any particular historical people-whether drafters, ratifiers, or commentators, however distinguished and significant within the drafting and ratification process they may have been - but rather the hypothetical understandings of a reasonable person who is artificially constructed by lawyers.").

${ }^{30}$ Heller, $128 \mathrm{~S}$. Ct. at 2826 (Stevens, J., dissenting) ("The contrast between those two declarations and the Second Amendment reinforces the clear statement of purpose announced in the Amendment's preamble. It confirms that the Framers' single-minded focus in crafting the constitutional guarantee 'to keep and bear arms' was on military uses of firearms, which they viewed in the context of service in state militias.").

${ }^{31}$ Id. at 2830-36. 
Court's precedent in United States v. Miller ${ }^{32}$ already resolved the issue in favor of a militia-based interpretation of the right to bear arms. ${ }^{33}$

Despite these differences, both the majority and the dissent were searching for some notion of original meaning underlying the Second Amendment based on its text, structure, and history. Justice Stevens examined: (1) the relationship between the operative clause and the prefatory clause, which the dissent believed established the limiting purpose of the Second Amendment (for "[a] well-regulated Militia"); ${ }^{34}$ (2) various state Declarations of Rights contemporaneous with the Declaration of Independence that spoke of the importance of a "well-regulated militia"; 35 (3) the meaning of "right of the people" and other references to "the people" in the Constitution; ${ }^{36}$ (4) the meaning of "to keep and bear Arms" by reference to contemporaneous dictionary definitions and uses of "arms" in state military laws; ${ }^{37}$ and (5) the connection between the Second Amendment and Article I's Militia Clauses as indicating an intent of the Framers to prevent Congress from disarming state militias. ${ }^{38}$

Although Stevens drew a different conclusion from these textual and historical sources than the majority, he engaged the debate at the same level the majority did: the historical time period of the Framing and some notion of the original meaning of the Second Amendment. ${ }^{39}$

\section{Importance of Text, History, and Original Meaning of the Second Amendment}

Constitutional law scholars will likely debate, for years to come, the interpretive approach of the Heller Court and its general significance for all of constitutional law. ${ }^{40}$ Plenty of prominent constitutional law scholars have already engaged that debate, post-Heller-critiquing and at times criticizing the Court's decision. ${ }^{41}$ Some historians

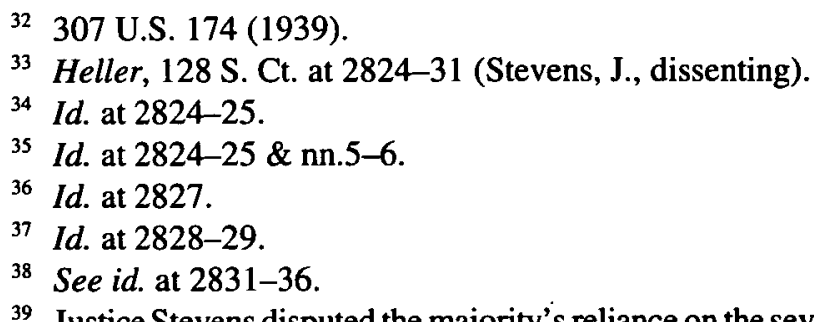

39 Justice Stevens disputed the majority's reliance on the seventeenth century Bill of Rights, Blackstone's Commentaries, and post-enactment commentary on the Second Amendment, all of which the dissent believed "offer[ed] little support for the Court's conclusion." Id. at 2837.

40 See, e.g., Larry Solum, Heller and Originalism Part I: Introduction to the Series, LEGAL THEORY BLOG, June 28, 2008, available at http://solum.typepad.com/legaltheory/ 2008/06/heller-and-the.html.

${ }^{41}$ See, e.g., Akhil Reed Amar, Heller, HLR, and Holistic Legal Reasoning, 122 HARV. L. Rev. 145 (2008); Reva B. Siegel, Dead or Alive: Originalism as Popular Constitutionalism in Heller, 122 HARV. L. REV. 191 (2008); Sunstein, supra note 4; Mark Tushnet, Heller and the New Originalism, 70 OHпо ST. L.J. (forthcoming 2009) (on file with author); J. Harvie Wilkinson, OfGuns, Abortions, and the Unraveling Rule of Law, 95 VA. L. REV. (forthcoming 
question the accuracy of the Heller Court's historical account. ${ }^{42}$ This Article does not join that larger debate, however, or evaluate the merits of the Heller decision, its history, or its reasoning. Whether the Heller case was "rightly decided," or whether it has significance for constitutional jurisprudence generally, I leave for others to analyze. This Article takes Heller as a starting point, or, in other words, as binding Second Amendment precedent (one that the Court is unlikely to overrule or disavow any time soon). Although the Court has dealt with the Second Amendment on a few occasions before, those cases did not provide much analysis of the historical origins of the Amendment, let alone the entire scope of the right to bear arms, notwithstanding the Heller dissent's assertions to the contrary. ${ }^{43}$ After years of ambiguity, Heller finally resolved a fundamental question about the basic nature of the Second Amendment right.

Taking Heller as a starting point, this Article discusses why Heller's profoundest effect may come in seemingly the unlikeliest of areas: not gun control laws, but copyright restrictions analyzed under the Free Press Clause-which, like the Second Amendment, not only deals with a technology, but has also remained largely unexamined in the Court's First Amendment cases.

\section{The TeXtual AND Historical CONNECTION BETWEEN THE SECOND AMENDMENT AND THE FREEDOM OF THE PRESS}

Drawing a connection between guns and the printing press, or between the right to bear arms and the freedom of the press, may seem like a non sequitur, at least to the modern sensibility. Guns shoot bullets; presses print books. Guns are weapons that can physically wound, maim, or even kill. Presses are machines that produce materials that stimulate the mind and spread human knowledge. Today, people do not typically associate guns and printing presses in the same breath. Historically, however, the Framing generation did. This Part explains why.

\section{A. The Constitution's Technologies: Guns and Speech Technologies}

\section{The Text of the First and Second Amendments}

In the entire Constitution, only two technologies are specifically recognized for protection as individual rights-the right to keep and bear "arms" and the freedom

Apr. 2009) (on file with author); Lawrence B. Solum, District of Columbia v. Heller and Originalism (Nov. 11, 2008) (unpublished manuscript), available at http://papers.ssrn.com/ sol3/papers.cfm?abstract_id=1241655.

${ }_{42}$ See Sunstein, supra note 4, at 252, 255-56 ("[M]any historians reject the Court's conclusion.").

${ }^{43}$ See Lewis v. United States, 445 U.S. 55, 65 n.8 (1980); United States v. Miller, 307 U.S. 174, 178 (1939); Presser v. Illinois, 116 U.S. 252, 264-66 (1886); United States v. Cruikshank, 92 U.S. 542, 551-53 (1875). 
of "the press." By "technology," I mean the same definition as it meant in the 1700s: "a treating of Arts or Workmanship." The "arts" likely referred in this context to the notion of useful arts or, in other words, practical know-how or technology. ${ }^{45}$ Thomas Sheridan defined "art" in 1780 as " $[t]$ he power of doing something not taught by nature and instinct; a science, as the liberal arts; a trade; artfulness, skill, dexterity; cunning." 46 In 1777, Samuel Johnson defined "art" in similar fashion. ${ }^{47}$ The "arts" were often associated with inventions and innovation. As Daniel Defoe wrote in 1727:

Nor could our relation of the improvement of Arts, and Science, Navigation, or Plantation, be satisfactory to the curious and enquiring Reader, if we did not give an account of those Arts and Sciences from their beginning, and tell who were the Inventors, who the Improvers, and who the Patrons of them through all the Ages of their improvement in the World. ${ }^{48}$

44 E. Coles, AN ENGLISH DictionaRY (London, Collins 1717).

${ }^{45}$ See U.S. ConsT. art. I, § 8, cl. 8, (Congress's power to "promote the Progress of Science and useful Arts"); 1 Donald ChISUM, CHISUM ON PATENTS \$1.01 (2007) ("The general purpose of the statutory classes of subject matter is to limit patent protection to the field of applied technology, what the United States [C]onstitution calls 'the useful arts."'). By contrast, literature and artistic endeavors were sometimes called the "polite" arts. See W. KENRICK, AN ADDRESS TO THE ARTISTS AND MANUFACTURERS OF GREAT BRITAIN, at vi-ix, 32 (London, 1774).

46 ThOMAS SHERIDAN, A GeNeral Dictionary OF THE ENGlish LaNGUAGE (London, Wogan 1784); see also TENCH COXE, AN ADDRESS TO AN ASSEMBLY OF THE FRIENDS OF AMERICAN MANUFACTURES 17-19 (Philadelphia, Aitken \& Son 1787) [hereinafter CoXe, AN ADDRESS] (discussing useful arts and manufacturing in England and early America).

47 SAMUEl JohnSON, A Dictionary OF THE ENGLISH LANGUAGE (London, Mifflin 4th ed. 1777). The Patent Act of 1793 defined the scope of patentable subject matter as "any new and useful art, machine, manufacture or composition of matter, or any new or useful improvement [thereof]." Patent Act of 1793, ch. 11, § 1, 1 Stat. 318 (1793) (emphasis added). As Karl Lutz explained, 'The term 'useful arts,' as used in the Constitution . . . is best represented in modern language by the word 'technology."' Karl B. Lutz, Patents and Science: A Clarification of the Patent Clause of the U.S. Constitution, 18 GEO. WASH. L. REV. 50, 54 (1949).

48 DANIEL DEFOE, A GENERAL HISTORY OF DISCOVERIES AND IMPROVEMENTS IN USEFUL ARTS, at v (1727); see also id. ("[S]o Invention, useful Undertakings, Arts, Science, all which were flourishing and encreasing at home under the Carthaginian Government, were likewise overwhelm'd in it, and all the Manufactures sunk with it ...."); Letter from Tench Coxe to James Madison (Mar. 21, 1790), reprinted in 13 PAPERS OF JAMES MADISON 112 (Charles F. Hobson \& Robert A. Rutland eds., 1981) [hereinafter PAPERS OF JAMES MADISON] ("I have the satisfaction to inform you that the Artist, who undertook to make the machine for spinning flax, hemp \& wool by water has completed the model \& that it is now in my hands ready for an application for a patent ...." (emphasis added)). For an excellent article on Daniel Defoe's influence in promoting the idea of a written constitution, see Bernadette Meyler, Daniel Defoe and the Written Constitution, 94 CORNELL L. REV. 73 (2008). 
The two "technology" provisions of the Constitution are worth quoting at length. The Second Amendment states, "A well regulated Militia, being necessary to the security of a free State, the right of the people to keep and bear Arms, shall not be infringed."49 The First Amendment states, "Congress shall make no law respecting an establishment of religion, or prohibiting the free exercise thereof; or abridging the freedom of speech, or of the press ...." No No other provision anywhere in the Constitution protects a specific technological device or machine. ${ }^{51}$ In this respect, the Second Amendment and the Free Press Clause are similar and exceptional.

\section{a. Similar: Constitutional Protection for Technologies}

First, the similarity. The eighteenth century meaning of "arms" and "press" both referred to technological devices. As Justice Scalia explained the meaning of "arms" in Heller:

The 1773 edition of Samuel Johnson's dictionary defined "arms" as "weapons of offence, or armour of defence." 1 Dictionary of the English Language 107 (4th ed.). Timothy Cunningham's important 1771 legal dictionary defined "arms" as "any thing that a man wears for his defence, or takes into his hands, or useth in wrath to cast at or strike another." $1 \mathrm{~A} \mathrm{New}$ and Complete Law Dictionary (1771); see also N. Webster, American Dictionary of the English Language (1828) (reprinted 1989) (similar). ${ }^{52}$

As I have recounted elsewhere, during the Framing, "the press" meant the printing press:

Indeed, the freedom of the press historically meant the freedom of the printing press. In seventeenth and eighteenth century England, "press" referred to the technology of the printing press or, more generally, to the publishing of any material by the printing press. ... Samuel Johnson's Dictionary of the English Language, for example, defined "press" in 1778 as "[t]he instrument by which books are printed." No definition included any reference to the modern understanding of the press as agents who report news.

49 U.S. CONST, amend. II (emphasis added).

so Id. amend. I (emphasis added).

51 The Patent Clause gives Congress the power to grant patents to "Discoveries" generally for "limited Times." Id. art. I, $\S 8, \mathrm{cl}$. 8. However, this Clause does not require any patents at all, absent Congress's enactment, and does not specify a certain invention for constitutional recognition.

52 District of Columbia v. Heller, 128 S. Ct. 2783, 2791 (2008). 
$\cdots$

At the time of the Framing, the term "the press" referred to the printing press. In fact, it was common to refer to the printing press simply as "the press." Thomas Sheridan's dictionary defined the press in 1780 as "the instrument by which books are printed"; no definition of "press" included journalists or news reporters as a collective group or institution. ${ }^{53}$

I do not argue that the Framers or the Framing generation necessarily thought of "arms" and the "press" as two related technologies. Nonetheless, I believe it is significant that they are the only man-made machines or devices specifically protected in the Bill of Rights, whether or not the Framers ever associated them together.

The principal (initial) drafter of both clauses, James Madison, often spoke of arms and the press in the same breath. For example, in his notes for his floor speech on June 8, 1789, in favor of the Bill of Rights, Madison grouped together as features or flaws of the English Declaration of Rights of 1688: "no freedom of press" as well as "arms to Protestts" only. ${ }^{54}$ Madison characterized both rights as "private rights." And writing years later, Madison spoke of both rights as vital to the Republic: "“[a] government resting on a minority is an aristocracy, not a Republic, ... and could not be safe with a numerical and physical force against it, without a standing army, an enslaved press, and a disarmed populace." "56

Madison was not alone in drawing a connection between arms and press in the Framing generation. As Randy Barnett and Don Kates have recounted, "James Madison, James Monroe, Fisher Ames, Albert Gallatin, and others mentioned the right to arms in the same breath with freedom of religion and press, and described them all and interchangeably as 'human rights,' 'private rights,' 'essential and sacred rights' which 'each individual reserves to himself." "57

To the modern sensibilities, the historical connection between arms and the press may seem odd. But, to the Framing generation, the connection would have been

53 Edward Lee, Freedom of the Press 2.0, 42 GA. L. REV. 309, 328-29, 339-40 (2008) (footnotes omitted); see also WILLAM RAWLE, A VIEW OF THE CONSTITUTION OF THE UNITED STATES OF AMERICA 123 (photo. reprint 2003) (Philadelphia, Philip H. Nicklin 2d ed. 1829) ("The press is a vehicle of the freedom of speech. The art of printing illuminates the world, by a rapid dissemination of what would otherwise be slowly communicated and partially understood.... Wherever a new settlement is formed, and every year presents many such, a printing press is established as soon as a sufficient number of inhabitants is collected.").

54 James Madison, Notes for Speech in Congress (ca. June 8, 1789), reprinted in 12 PAPERS OF JAMES MADISON, supra note 48, at 193-94.

s5 Id. (describing "freedom of press-Conscience ... arms" as "private rights").

56 RALPH KETCHAM, JAMES MADISON: A BIOGRAPHY 640 (1971) (emphasis added).

${ }^{57}$ Randy E. Barnett \& Don B. Kates, Under Fire: The New Consensus on the Second Amendment, 45 EMORY L.J. 1139, 1176 (1996). 
commonsensical. The right to bear arms and the freedom of the press presented the exact same type of question for the Framers: can there ever be a natural right to a man-made device? In the case of arms and presses, the Framers believed so. ${ }^{58}$

That both technologies were incredibly revolutionary devices developed during the same era made it logical for commentators to discuss the two together. For example, as Defoe wrote in 1725 :

As Printing was invented by Koster in 1428, or 1430, Rag Paper in 1452, so Graving, and Printing by the Rolling Press was brought on in 1460, and Etching a few Years after in like manner: By the like degrees Gunpowder was the Invention of the same Century, and Guns follow'd it close at the Heels; it was impossible that Powder could be known, and the force of it, and Nature not direct Men to fight with it. ${ }^{59}$

Significantly, Defoe described both printing and the making of gunpowder as "arts," which in this context undoubtedly meant a form of technology. ${ }^{60}$

58 Id. at 1172 ("The fact that Madison and his colleagues believed individuals had a natural right both to freedom of speech and to possess arms for self-defense is crucial evidence that they meant exactly what they said in guaranteeing 'the right of the people to keep and bear arms." "); see also FRANCIS LUDLOW HOLT, THE LAW OF LIBEL 52 (London, J. Butterworth and Son $2 d$ ed. 1816) (discussing freedom of the press and concluding " $t$ the same character, therefore, of natural rights is conveyed to every right which is natural in its origin and principle, through all the possible modes and instruments of exercising and launching it into action...").

59 DEFOE, supra note 48, at 226 (emphasis added).

60 Id. at 223 ("From hence I must pass to another perfectly new Invention or Improvement, which the World owes to the same Northern Climate, tho' not the same Country as the other; namely, the Art of Printing." (emphasis added)); id. at 227 ("Why did not Providence permit the first Invention of Powder to be so appropriated to one particular Prince or Nation, that they might have conceal'd the Art of making it . ..." (emphasis added)); id. at 229 ("I am told by some, that the Improvements in the Art of War are such, and so considerable, that no other Improvements can come up to them; also that these Improvements ought to take a Place in the Discourse I am upon, and I grant it; but then I think the proper Ephocha to begin our Discourse upon warlike Improvements, shou'd begin at the Introduction of Guns and Gunpowder ...." (first and third emphasis added)); see also People v. Toynbee, 2 Parker Crim. Rep. 329, 347-48 (N.Y. 1855) ("Here are a class of citizens who have invested their property and spent the best years of their lives in learning and establishing a particular business or trade, inoffensive and commendable in itself - the growth and manufacture, it may be, of wine, the culture of barley and hops, the manufacture of firearms and gunpowder, the fabrication of types, printing presses and paper, and then comes a legislative act, confessing its incompetency to invade or disturb existing interests, and declares that because wine and the decoction of barley and hops may lead to intoxication, fire arms and gunpowder to war, bloodshed and the destruction of human life; and types, printing presses and paper to blasphemous, libelous and obscene publications, all future acquisitions of the kind shall cease to be regarded as property, and be no longer entitled to claim the benefit and protection of the laws." (emphasis added)). 
Tench Coxe, a prominent lawyer from Philadelphia who served as a Pennsylvania delegate to the Confederation Congress, was one of the most vocal advocates for economic and technological progress in early America and wrote several important works on that topic. ${ }^{61}$ Coxe, too, described guns and printing both as products of industrial advancement. ${ }^{62}$ Though a Federalist, he, like Madison, eventually supported the recognition of the freedom of the press and the right to bear arms in the Bill of Rights. As Coxe wrote in 1789:

The following paragraph declares the freedom of the press to be a main bulwark of liberty, and reasoning unanswerably from its usefulness and indispensable necessity, declares, that it shall be inviolable.

As civil rulers, not having their duty to the people, duly before them, may attempt to tyrannize, and as the military forces which shall be occasionally raised to defend our country, might pervert their power to the injury of their fellow-citizens, the people are confirmed by the next article in their right to keep and bear their private arms. ${ }^{63}$

61 See, e.g., COXE, AN ADDRESS, supra note 46; TENCH COXE, A VIEW OF THE UNITED STATES OF AMERICA (Philadelphia 1794) [hereinafter COXE, A VIEW].

62 COXE, A VIEW, supra note 61, at 39 ("By wind and water machines we can make pig and bar iron, nail rods, tire, sheet-iron, sheet-copper, sheet-brass, anchors, meal of all kinds, gun-powder, writing, printing and hanging paper ...." (emphasis added)); id. at 64 ("Papermills, gun-powder-mills, steel works, rolling and slitting mills, printing figured goods of paper, linen, and even of cotton, coach making, book printing, and several other branches, are wonderfully advanced: and every month seems to extend our old manufactures, or to introduce new ones." (emphasis added)).

${ }^{63}$ Tench Coxe, Remarks on the First Part of the Amendments to the Federal Constitution, Moved on the 8th Instant in the House of Representatives, PHILA. FED. GAZETTE, June 18, 1789, reprinted in THE ORIGIN OF THE SECOND AMENDMENT: A DOCUMENTARY HISTORY OF THE BIL OF RIGHTS 671 (David E. Young ed., 2d ed.1995) [hereinafter THE ORIGIN OF THE SECOND AMENDMENT]. For more of Coxe's writings on the Bill of Rights, see Tench Coxe, Remarks on the Second Part of the Amendments, Moved on the 8th Instant in the House of Representatives, PHILA. FED. GAZETTE, June 30, 1789, reprinted in THE ORIGIN OF THE SECOND AMENDMENT, supra, at 674-75 ("The fifth proposition is an admirable thought. The Congress of the United States not only declare that liberty of conscience-the freedom of the press-and trial by jury are due from them to the people of this Union, but deeming them as precious as the Republican form of our government, they declare, that no State under pretence of a separate jurisdiction, shall violate either of them."); Letter from Tench Coxe to James Madison (June 18, 1789), reprinted in THE ORIGIN OF THE SECOND AMENDMENT, supra, at 672 ("Those who are honest are well pleased at the footing on which the press, liberty of conscience, original right \& power, trial by jury \&ca. are rested . . . I . . f feel very great satisfaction in being able to assure you generally, that the proposed amendments will greatly tend to promote harmony among the late contending parties and a general confidence in the patriotism of Congress."). 
It is also significant that five of the eight states that proposed amendments during the ratification of the Constitution offered proposals for protecting the freedom of the press (Maryland, New York, North Carolina, Pennsylvania, Virginia), ${ }^{64}$ while five states also proposed the right to bear arms (New Hampshire, New York, North Carolina, Pennsylvania, Virginia). ${ }^{65}$ And of these states, Pennsylvania, Virginia, and North Carolina, three very influential states, placed the proposals for the freedom of the press and the right to bear arms consecutively or back-to-back ${ }^{66}$-which is how eventually they came to be ordered in the Bill of Rights in what became the First and Second Amendments. In their state constitutions and declarations of rights, Massachusetts (1780), Pennsylvania (1776), and Vermont (1777) also listed the protections for the freedom of the press and the right to bear arms consecutively. ${ }^{67}$

To the Framing generation, the right to bear arms was important to self-defense and the ability to defend against the tyranny of the state. ${ }^{68}$ Likewise, the right to the freedom of the press was important to self-expression, as well as to defend against the tyranny of the state. As the Continental Congress explained the importance of the freedom of the press in 1774 :

The importance of this [freedom of the press] consists, besides the advancement of truth, science, morality, and arts in general, in its diffusion of liberal sentiments on the administration of Government, its ready communication of thoughts between subjects, and its consequential promotion of union among them, whereby oppressive officers are shamed or intimidated, into more honourable and just modes of conducting affairs. ${ }^{69}$

Likewise, as the Federal Farmer championed the right to bear arms in 1788: "To preserve liberty, it is essential that the whole body of the people always possess arms, and be taught alike, especially when young, how to use them."70 While the right to

642 BERNARD SCHWARTZ, THE BILL OF RIGHTS: A DOCUMENTARY HISTORY 983 (1971) [hereinafter SCHWARTZ, THE BILLOFRIGHTS]; id. at 658 (Pennsylvania); id. at 734 (Maryland); id. at 842 (Virginia); id. at 913 (New York); id. at 968 (North Carolina).

${ }^{65}$ Id. at 658 (Pennsylvania); id. at 761 (New Hampshire); id. at 842 (Virginia); id. at 912 (New York); id. at 968 (North Carolina).

66 Id. at 658 (Pennsylvania); id. at 842 (Virginia); id. at 968 (North Carolina).

671 SCHWARTZ, THE BILL OF RIGHTS, supra note 64, at 266 (Pennsylvania); id. at 324 (Vermont); $i d$. at 342 (Massachusetts). Ten of the twelve original states recognized the freedom of the press in their constitutions, while eight also recognized some of the same concerns that later were addressed in the Second Amendment in a variety of different clauses. See L.A. Powe, Jr., Guns, Words, and Constitutional Interpretation, 38 WM. \& MARY L. REV. 1311, 1350 (1997).

68 See District of Columbia v. Heller, 128 S. Ct. 2783, 2800-01 (2008).

69 HENRY MIDDLETON, ADDRESS TO THE INHABITANTS OF QUEBEC (1774), reprinted in 1 SCHWARTZ, THE BILL OF RIGHTS, supra note 64, at 223.

${ }^{70}$ LETTERS FROM THE FEDERAL FARMER TO THE REPUBLICAN 124 (Walter Hartwell Bennett ed., 1978). 
bear arms was important for self-defense and the freedom of the press for selfexpression, both were considered fundamental to liberty and were each described separately in the Framing era as the "palladium of liberty."71 The disarming of the populace and the destruction of printing presses were anathemas to a free state-as the Second Amendment ("A well regulated Militia, being necessary to the security of a free State ....") 72 and Blackstone in his influential Commentaries ("The liberty of the press is indeed essential to the nature of a free state ....") ${ }^{73}$ both recognized.

In 1799, this connection between arms and presses, and the whole concept of liberty and a free state, was made clear during the turmoil between the Federalists and Republicans (i.e., Anti-Federalists). As Stephen Halbrook and David Kopel have recounted:

By mid-1799, ... armed conflict between Federalists and Republicans threatened. The Aurora published reports of bullying, weapons brandishing, and rioting by soldiers in the Federalist faction. In retaliation, a mob of "federal savages" attacked and beat Aurora editor William Duane. As a consequence of the mob's threat to destroy the press, "a number of Republican citizens collected with arms and ammunition, continue to mount guard in the Printing-Office." 74

As this incident shows, the citizens in this conflict would have been unable to protect their printing press from destruction without the right to bear arms.

In short, both rights protect individual liberty, ${ }^{75}$ and guard against tyrannical governments. ${ }^{76}$ As Professor Sanford Levinson has explained:

71 See 1 ST. GEORGE TUCKER, BLACKSTONE's COMMENTARIES 300 (Philadelphia, William Young Birch \& Abraham Small 1803) ("[The Second Amendment] may be considered as the true palladium of liberty."); see also XIII THE DOCUMENTARY HISTORY OF THE RATIFICATION OF THE CONSTITUTION: 1 COMMENTARIES ON THE CONSTITUTION PUBLIC AND PRIVATE 479 (1981) ("The press is the scourge of tyrants and the grand palladium of liberty."). For more on St. George Tucker's broad understanding of the freedom of the press and the right to bear arms, see Powe, supra note 67, at 1369-70.

72 U.S. CONST. amend. II.

73 WILLIAM BLACKSTONE, 4 COMMENTARIES *151.

74 Stephen P. Halbrook \& David B. Kopel, Tench Coxe and the Right to Keep and Bear Arms, 1787-1823, 7 WM. \& MARY BILL RTS. J. 347, 371 (1999).

75 At the time of the Framing, it was far more common for households to own guns than printing presses. During the Framing generation, gun ownership for protection and hunting purposes was common. See Clayton E. Cramer \& Joseph Edward Olson, Pistols, Crime, and Public: Safety in Early America, 44 WILAMETTE L. REV. 699, 710-11 (2008). By comparison, the printing press was not a household device, but instead a machine for those engaged in publishing —estimated to be 200 in number in 1798. See Thomas B. Nachbar, Constructing Copyright's Mythology, 6 GREEN BAG 37, 45 (2002).

76 See J.M. Balkin \& Sanford Levinson, The Canons of Constitutional Law, 111 HARV. L.REV. 963, 1013 n.157 (1998) ("These implications should be especially important for anyone 
Scholars of the First Amendment have made us aware of the importance of John Trenchard and Thomas Gordon, whose Cato's Letter's were central to the formation of the American notion of freedom of the press. That notion includes what Vincent Blasi would come to call the "checking value" of a free press, which stands as a sturdy exposer of governmental misdeeds. Consider the possibility, though, that the ultimate "checking value" in a Republican polity is the ability of an armed populace, presumptively motivated by a shared commitment to the common good, to resist governmental tyranny. Indeed, one of Cato's letters refers to "the Exercise of despotick Power [as] the unrelenting War of an armed Tyrant upon his unarmed Subjects. . ."77

One need look no further than the American Revolution itself to understand the necessity of the freedom of the press and the right to bear arms as safeguards of liberty, and as weapons of the right of revolution against a tyrannical state. ${ }^{78}$

\section{b. Exceptional: Only Two "Technology" Provisions in Bill of Rights}

Now let us turn to the exceptional quality shared by the freedom of the press and the right to bear arms. The Framers singled out, by name, only two technologies for express protection in the Bill of Rights_- "arms" and "press"-in amendments that follow each other. ${ }^{79}$ I believe it is worth dwelling on this basic textual similarity shared by the two clauses. It is one so easy to overlook. As a textual matter, the connection between the two technologies is suggestive (and, as I later show, the history of the Framing is confirmatory).

The constitutional method I rely on is what Professor Akhil Amar has championed as intratextualism-i.e., "[i]n deploying this technique, the interpreter tries to

who emphasizes the 'checking value' that underlies the free speech and press provisions of the First Amendment, for there can be little doubt that many members of the founding generation viewed popular possession of arms as the ultimate 'check' on corrupt governments."). But see Saul Cornell, Commonplace or Anachronism: The Standard Model, the Second Amendment, and the Problem of History in Contemporary Constitutional Theory, 16 CONST. COMMENT. 221, 229-30 (1999) ("While this comparison is instructive, it rests on an historically questionable reading of the way the press functioned in post-revolutionary America. While leading Pennsylvania Constitutionalists certainly believed in freedom of the press, these same individuals also accepted the notion of seditious libel.").

77 Sanford Levinson, The Embarrassing Second Amendment, 99 YALEL.J. 637, 648 (1989).

78 See Powe, supra note 67, at 1365 ("Words and guns enabled a successful revolution, and it is not surprising that the founding generation thought highly of both. William Cushing, Chief Justice of the Supreme Judicial Court of Massachusetts, wrote in a letter to John Adams: 'Without this liberty of the press could we have supported our liberties against british administration? or could our revolution have taken place? Pretty certainly it could not.'”).

${ }^{79}$ U.S. CONST. amends. I \& II. 
read a contested word or phrase that appears in the Constitution in light of another passage in the Constitution featuring the same (or a very similar) word or phrase." More generally, my proposed method of constitutional interpretation of the Free Press Clause follows what Professor Laurence Tribe has described as " $[t]$ reating the text in a holistic way." ${ }^{, 11}$ My basic insight is this: given that they both protect technologies, and are the only two clauses in the Constitution that do so expressly, the Free Press Clause and the Second Amendment can provide insights to understanding each respective clause.

This interpretive principle is similar to the in pari materia canon of construction. In the statutory context, courts entertain this canon, under which "statutes addressing the same subject matter generally should be read 'as if they were one law." case of the Constitution, I am suggesting something similar, albeit perhaps weaker, than the in pari materia canon: provisions addressing the same subject matter generally (or same genus) may be worth consulting holistically to interpret one or the other provision, at least as a form of persuasive authority.

A clear example of this dynamic is provided by criminal law protections. For example, the Fifth Amendment right against self-incrimination (i.e., against being "compelled in any criminal case to be a witness against himself") ${ }^{83}$ and the Sixth Amendment right to "the Assistance of Counsel for his defence"84 are not similar looking in language. Yet they both fall within the larger genus of protections for criminal defendants, including, specifically, the protections during police interrogation. Thus, as protections related to police interrogations, the two amendments each may offer helpful precedents for interpreting the other. In Michigan v. Jackson, the Supreme Court drew upon its prior interpretation of the Fifth Amendment right against self-incrimination (that requires custodial interrogation to cease after a defendant has asked for counsel) in Edwards v. Arizona and applied nearly the same interpretation of the right to counsel during interrogation under the Sixth Amendment after a defendant has been arraigned. ${ }^{85}$ Likewise, the Supreme Court has interpreted the due process test of prejudice for a prosecutor's failure to disclose exculpatory evidence under Brady under the same standard for judging prejudice under the Sixth

80 Akhil Reed Amar, Intratextualism, 112 HARV. L. REV. 747, 748 (1999).

81 LAURENCE H. TRIBE, THE INVISIBLE CONSTITUTION 74 (2008); see also Balkin \& Levinson, supra note 76, at 1013 (arguing for holistic examination of Bill of Rights and recognition that "the component parts of the Bill of Rights are interrelated").

${ }^{82}$ Wachovia Bank, Nat'l Ass'n v. Schmidt, 546 U.S. 303, 305 (2006) (quoting Erlenbaugh v. United States, 409 U.S. 239, 243 (1972)).

${ }^{83}$ U.S. ConST. amend. V.

${ }^{84}$ Id. amend. VI.

85 See Michigan v. Jackson, 475 U.S. 625, 629 (1986) (discussing Edwards v. Arizona, 451 U.S. 477, 482 (1981)). In 2009, the Supreme Court requested supplemental briefing in a case, asking whether Michigan v. Jackson should be overruled. See Montejo v. Louisiana, No. 07-1529, 2009 WL 793514, at *1 (U.S. March 27, 2009). 
Amendment protection against ineffective assistance of counsel.$^{86}$ In these examples, the text of the constitutional provisions is not similar in language, yet they encompass things that fall within a larger genus-e.g., the right to counsel during interrogation and prejudice that arises from an impropriety in a criminal prosecution.

The Copyright and Patent Clauses provide another clear example of constitutional provisions addressing the same general subject matter that the Court sometimes interprets in similar fashion. First, there can be no doubt that the two clauses address the same general subject matter of "exclusive right," given the way the two clauses are written and interlaced together: Congress shall have the power " $[t] 0$ promote the Progress of Science and useful Arts, by securing for limited Times to Authors and Inventors the exclusive Right to their respective Writings and Discoveries." 87 Although the Court has recognized that copyrights and patents sometimes raise different concerns, it has often drawn upon copyright or patent cases for its analysis of the other. ${ }^{88}$

Granted, the criminal law protections in the Bill of Rights and the Patent and Copyright Clauses are much easier to identify for possible holistic interpretation. The thread tying them together is tight and obvious - criminal investigation and prosecutions, and the grant of "exclusive right," respectively. In the case of "arms" and "press," however, the connection, if any, is far from clear. The inclusion of both "arms" and "press" could be pure coincidence. There is no single event (like a criminal trial) or term ("exclusive right") that necessarily connects the two.

Yet it is important to recognize the need for exploring the possibility of a connection here, instead of dismissing it out of hand. Silence sometimes is striking. The Constitution does not mention the wheel, abacus, watch, telescope, or microscope for protection, notwithstanding their revolutionary advancements before the Framing. Instead, the Constitution only specifies "arms" and "press." That's it.

The singularity of these two technologies in the Bill of Rights, coupled with the common references to both technologies by Madison, Coxe, Defoe, and others in the same passages, warrants further examination. Had the Bill of Rights recognized instead a "freedom of the microscope" and the "right of the people to keep and use telescopes" in two consecutive amendments, it would be hard to deny the need for investigating a possible connection between the two. The "freedom of the press" and "right to bear and keep arms" should merit the same. Employing a method of

86 See Kyles v. Whitley, 514 U.S. 419, 434 (1995) (stating that for a Brady violation, "[a] 'reasonable probability' of a different result is accordingly shown when the government's evidentiary suppression 'undermines confidence in the outcome of the trial"'); Strickland v. Washington, 466 U.S. 668, 695 (1984) ("When a defendant challenges a conviction, the question is whether there is a reasonable probability that, absent the errors, the factfinder would have had a reasonable doubt respecting guilt."). 
intratextualism, ${ }^{89}$ and examining the Constitution holistically, should give us at least pause at the inclusion of two words in the Constitution that appear to fall within the same genus (technology)-which is rarely mentioned in the Constitution. The following sections identify other textual and historical connections between the right to bear arms and the freedom of the press that provide an even stronger reason for the Court to consult its Heller decision in interpreting the Free Press Clause.

\section{Textual Similarities Between the Freedom of the Press and the Right to Bear} Arms in State Constitutions and Earlier Drafts of the Bill of Rights

Another textual similarity between the freedom of the press and the right to bear arms can be found in several state constitutions. As Eugene Volokh has noted in an insightful essay, the provisions recognizing the freedom of the press in the state constitutions of Massachusetts (1780), New Hampshire (1784), Rhode Island (1842), North Carolina (1776), and Pennsylvania (1776) all had a "justification" or "prefatory" clause, a feature that distinguishes the Second Amendment from all other provisions in the Bill of Rights. ${ }^{90}$ Thus, the unique verbiage and structure of the Second Amendment with a prefatory clause in the Constitution was, in fact, emulated in free press clauses containing prefatory clauses in state constitutions.

For example, the Massachusetts Constitution stated in 1780, in language strikingly similar to the Second Amendment's prefatory clause, "The liberty of the press is essential to the security of freedom in a state: it ought not, therefore, to be restrained in this Commonwealth." ${ }^{\prime 11}$ Likewise, Rhode Island's free press clause stated in 1842, "The liberty of the press being essential to the security of freedom in a state, any person may publish sentiments on any subject, being responsible for the abuse of that liberty...."92 The Second Amendment contains remarkably similar language in its prefatory or justification clause about the necessity of a well-regulated militia "to the security of a free State."93

89 Admittedly, I may be expanding intratextualism beyond Amar's own brand of intratextualism. The words "arms" and "press" are not the same or similar looking, in contrast with the several uses of "inferior," "the people," or other terms in the Constitution. See Amar, supra note 80 . Instead, they are similar in that they fall within a larger genus, class of thing, or subject matter-here, a technology or art. However, Amar does recognize the kind of holistic textualism I am relying on as a legitimate approach that is consistent with his theory. Id. at 796 ("The particular type of intratextualism that I am highlighting here harmonizes nicely with other forms of holistic textualism. Even if adjoining clauses have no linguistic overlap, they often deal with related subjects, and each is often illuminated by careful comparison with its neighbors.").

90 Eugene Volokh, The Commonplace Second Amendment, 73 N.Y.U.L. REV. 793, 794-95, 814 (1998).

91 MASS. CONST. art. XVI (1780), superceded by MASS. CONST. art. LXXVII, reprinted in 1 SCHWARTZ, THE BILL OF RIGHTS, supra note 64, at 342 (emphasis added).

92 R.I. CONST. art. I, \$ 20 (emphasis added).

93

U.S. CONST. amend. II. 
Although the Free Press Clause in the Bill of Rights does not contain any justification or prefatory clause, Virginia's proposal ${ }^{94}$ and James Madison's original proposal for the Free Press Clause ${ }^{95}$ both did. My conjecture is that the justification clause for the Free Press Clause became expendable or unwieldy during the drafting process as the First Congress joined several different rights-i.e., the Free Exercise and Establishment Clauses, the Free Speech and Free Press Clauses, the Assembly and Petition Clauses-in one amendment. ${ }^{96}$

The importance of the freedom of the press and the right to bear arms was apparent in the ratification debates. For example, during the ratification of the Constitution in Massachusetts, Samuel Adams proposed amending the Constitution:

And that the said Constitution be never construed to authorize Congress to infringe the just liberty of the press, or the rights of conscience; or to prevent the people of the United States, who are peaceable citizens, from keeping their own arms; or to raise standing armies, unless when necessary for the defence of the United States, or of some one or more of them; or to prevent the people from petitioning, in a peaceable and orderly manner, the federal legislature, for a redress of grievances; or to subject the people to unreasonable searches and seizures of their persons, papers or possessions. ${ }^{97}$

Significantly, Adams placed the freedom of the press and the right to bear arms consecutively and at the opening of his proposal. Although Adams eventually withdrew his proposal, a letter to the editor in Philadelphia argued that Adams had been vindicated by Congress's consideration of "every one of [Adams's] intended alterations, but one . . ."98 Notably, an early draft of the Bill of Rights in the House (dated Aug. 24, 1789) used similar language in recognizing the freedom of the press and the right to bear arms both as rights that "shall not be infringed." 99 These several

942 SCHWARTZ, THE BLLOF RIGHTS, supra note 64, at 842 ("That the people have a right to freedom of speech, and of writing and publishing their sentiments; that the freedom of the press is one of the greatest bulwarks of liberty, and ought not to be violated.").

95 Id. at 1026 ("The people shall not be deprived or abridged of their right to speak, to write, or to publish their sentiments; and the freedom of the press, as one of the great bulwarks of liberty, shall be inviolable.").

${ }^{96}$ For a detailed recounting of the various versions and proposals for what later became the First Amendment, see Lee, supra note 53, at 347-48.

97 Excerpts of Massachusetts Convention (Feb. 6, 1788), reprinted in THE ORIGIN OF THE SECOND AMENDMENT, supra note 63, at 260 (emphasis added).

98 Letter to the Editors, PHILA. INDEP. GAZETEER, Aug. 20, 1789, reprinted in THE ORIGINS OF THE SECOND AMENDMENT, supra note 63, at 701-02.

99 See Proceedings of the House of Representatives, Aug. 24, 1759, reprinted in THE ORIGINS OF THE SECOND AMENDMENT, supra note 63, at 706-07. 
examples demonstrate that the freedom of the press and the right to bear arms were concepts set forth in very similar language in state constitutions and early drafts of the Bill of Rights.

\section{B. Comparing the Historical Development of the Right to Bear Arms and the} Freedom of the Press

Even beyond the textual connection between "arms" and "press" in the Constitution, there is a striking similarity in the historical development of the right to bear arms and the freedom of the press. Arms and presses both were subject to severe governmental restrictions in seventeenth-century England until a backlash against the restrictions led to their demise. ${ }^{100}$ That history in England informed the Framers, the ratifying states of the U.S. Constitution, and the First Congress, sparking very similar debates on the need for their express protection in the Constitution during the ratification.

\section{The Right to Keep and Bear Arms}

As Justice Scalia explained in much greater detail in Heller, ${ }^{101}$ the historical development of the concept of a right to bear arms dates back to seventeenth-century England in reaction to the Crown's abuses. ${ }^{102}$ Specifically, "the Stuart Kings Charles II and James II succeeded in using select militias loyal to them to suppress political dissidents, in part by disarming their opponents." ${ }^{\text {103 }}$ For example, the Militia Act of 1662 gave royally appointed militia officers the power "to search for and seize all arms" of anyone they judged "dangerous to the peace of the kingdom." 104

In reaction, Protestants were able to convince William and Mary to recognize a provision in the Declaration of Right (1689) to protect Protestants from disarmament: "That the subjects which are Protestants may have arms for their defense suitable to their conditions and as allowed by law."105 This provision was a precursor to the more general notion of the right to bear arms. In his Commentaries, Blackstone

100 See Peter Lanston Fitzgerald, An English Bill of Rights? Some Observations from Her Majesty's Former Colonies in America, 70 GEO. L.J. 1229, 1232-35 (1982) (noting that with the enactment of the $1689 \mathrm{Bill}$ of Rights, "English liberty was assured protection from illegal action by the Crown," and that the Bill of Rights ensured that "English rights and freedoms" would then be enforced).

101 I do not attempt to critique the accuracy of the historical accounts of the Second Amendment by the majority or the dissent. Instead, I take the majority's narrative as a "given," so to speak, because it is the historical account that figured into the Court's ultimate decision.

102 District of Columbia v. Heller, 128 S. Ct. 2783, 2798 (2008).

103 Id.

$1041662,13 \& 14$ Car. 2, c. $3, \S 14$.

105 Heller, 128 S. Ct. at 2798 (quoting 1689, 1 W. \& M., c. 2, § 7). 
described this provision in the Declaration of Right as protecting "the natural right of resistance and self-preservation" and "the right of having and using arms for selfpreservation and defence." 106

This same saga would play out in the American colonies during the 1760 s and 1770 s, when George III attempted to disarm the colonists, which sparked protest among them against the Crown. ${ }^{107}$ Against this backdrop, the debate over the Second Amendment was framed. As Justice Scalia recounted:

The debate with respect to the right to keep and bear arms, as with other guarantees in the Bill of Rights, was not over whether it was desirable (all agreed that it was) but over whether it needed to be codified in the Constitution. During the 1788 ratification debates, the fear that the federal government would disarm the people in order to impose rule through a standing army or select militia was pervasive in Antifederalist rhetoric. See, e.g., Letters from The Federal Farmer III (Oct. 10, 1787), in 2 The Complete Anti-Federalist 234, 242 (H. Storing ed. 1981). John Smilie, for example, worried not only that Congress's "command of the militia" could be used to create a "select militia," or to have "no militia at all," but also, as a separate concern, that "when a select militia is formed; the people in general may be disarmed." 2 Documentary History of the Ratification of the Constitution 508-509 (M. Jensen ed. 1976). Federalists responded that because Congress was given no power to abridge the ancient right of individuals to keep and bear arms, such a force could never oppress the people. See, e.g., A Pennsylvanian III (Feb. 20, 1788), in The Origin of the Second Amendment 275, 276 (D. Young ed., 2d ed. 2001); White, To the Citizens of Virginia, Feb. 22, 1788, in id., at 280, 281; A Citizen of America, (Oct. 10, 1787) in id., at 38,40; Remarks on the Amendments to the federal Constitution, Nov. 7,1788 , in id., at 556. ${ }^{108}$

In the end, the Anti-Federalist argument carried the day, and the right to keep and bear arms was expressly codified in the Second Amendment.

\section{The Freedom of the Press}

The history of the freedom of the press followed a remarkably similar course. In prior scholarship, I have recounted, at length, the history of the freedom of the

106 Id. (quoting WILLAM BLACKSTONE, 1 COMMENTARIES *139-40). 
press from England to the early United States, so I will only summarize the main highlights here. ${ }^{109}$

Just as with the right to bear arms, the historical development of the concept of the freedom of the press dates back to the abuses of the Crown in restricting the technology in order to suppress political and religious dissent. ${ }^{110}$ The press restrictions began in 1538 under Henry VIII and continued until the early 1700 s, including through the Stuart reign. ${ }^{11}$

A major part of the repressive regime in England were the Printing Acts, ${ }^{112}$ which, not only required prepublication licensing of every work, ${ }^{113}$ but also restricted and even attempted to reduce the total number of presses in England. ${ }^{114}$ The Printing Acts helped to entrench the Stationers' Company, a guild of printers and publishers who effectively held a monopoly over the presses as well as the copyrights to nearly all works. ${ }^{115}$ No work could be published without registration in the Stationers' Company; all printing presses had to be registered with the Company as well. ${ }^{116}$

109 Lee, supra note 53, at 319-56.

110 Id. at 320-23.

111 Id.

112 Printing Acts were enacted in 1643, 1647, 1649, 1653, 1662, 1664, 1665, 1685, and 1692. See An Ordinance for the Regulating of Printing, 1643 [hereinafter Printing Act of 1643], reprinted in 1 ACTS AND ORDINANCES INTERREGNUM, 1642-1660, at 184 (C.H. Firth \& R.S. Rait eds., 1978) (1911) [hereinafter ACTS AND ORDINANCES]; An Ordinance against unlicensed or scandalous Pamphlets, and and for the better Regulating of Printing, 1647, reprinted in 1 ACTS AND ORDINANCES, supra, at 1021; An Act against Unlicensed and Scandalous Books and Pamphlets, and for better regulating of Printing, 1649, reprinted in 2 ACTS AND ORDINANCES, supra, at 245; An Act for reviving of a former Act, Entituled, An Act against Unlicensed and Scandalous Books and Pamphlets, and for Regulating of Printing, with some Additions and explanations, 1653, reprinted in 2 ACTS AND ORDINANCES, supra, at 696; An act for preventing abuses in printing seditious, treasonable, and unlicensed books and pamphlets, and for regulating of printing and printing-presses, 1662, 13 \& $14 \mathrm{Car}$. 2, c. 33 [hereinafter Printing Act of 1662]; An act for continuance of a former act for regulating the press, 1664, $16 \& 17$ Car. 2, c. 7; An act for continuance of a former act for regulating the press, $1664,17 \mathrm{Car} .2$, c. 4; An act for reviving and continuance of several acts of parliament therein mentioned, 1685, 1 Jac. 2, c. 17; An act for reviving, continuing, and explaining several laws therein mentioned, which are expired and near expiring, 1692, 4 W. \& M., c. 24.

The predecessor regime under the Star Chamber decrees, which ended in 1640, were equally as oppressive and provided the basic blueprint for the Printing Acts. See Star Chamber Decree of 1566 , reprinted in 1 A TRANSCRIPT OF THE REGISTERS OF THE COMPANY OF STATIONERS OF LONDON, 1554-1640, at 145b (Edward Arber ed., 1875) [hereinafter STATIONERS OF LONDON]; Star Chamber Decree of 1586, reprinted in 2 STATIONERS OF LONDON, supra, at 807; Star Chamber Decree of 1637, reprinted in 4 STATIONERS OF LONDON, supra, at 529.

113 For more on the prepublication licensing requirement, see JOHN FEATHER, A HISTORY OF BRITISH PUBLISHING 36-37 (2d. ed. 2006).

114 Lee, supra note 53, 321-22.

115 Id. at 320-22.

116 Id. at 321. 
Backed by a royal charter ${ }^{117}$ and the Printing Acts, the Stationers had the power to conduct warrantless searches and confiscate illegal presses, ${ }^{118}$ in a way similar to how the royally backed militia officers could seize arms under the Militia Act of 1662.

For example, the Printing Act of 1643 stated:

[T]he Master and Wardens of the said Company ... are hereby Authorized and required, from time to time, to make diligent search in all places, where they shall think meet, for all unlicensed Printing Presses, and all Presses any way imployed in the printing of scandalous or unlicensed Papers, Pamphlets, Books, or any Copies of Books belonging to the said Company, or any member thereof, without their approbation and consents, and to seize and cary away such Printing Presses Letters, together with the Nut, Spindle, and other materials of every such irregular Printer, which they find so misimployed, unto the Common Hall of the said Company there to be defaced and made unserviceable according to ancient Custom .... ${ }^{119}$

Thus, one of the key components of the Printings Acts was their attempt to control the perceived "licentiousness" of the press, including copyright infringement and unauthorized printings in England, by limiting the technology itself. As the Printing Act of 1662 expressly stated, there was "no surer means" of controlling licentiousness than "by reducing and limiting the number of printing-presses, and by ordering and settling the said art or mystery of printing by act of parliament, in manner as herein after is expressed.", 120

To that end, the Printing Acts imposed a strict regime of technology restrictions in England. Indeed, the Printing Act of 1662 sought to reduce the total number of printing presses allowed in England to just forty. ${ }^{121}$ By restricting the technology,

117 Philip and Mary granted the Stationers' Company its first royal charter in 1557, which Elizabeth I expanded in 1586. Id. at 320-21. The royal charter gave the company the sweeping power to search houses and businesses of all printers and book sellers for unauthorized materials and presses. Id. at 321-22; see also 1 STATIONERS OF LONDON, supra note 112, at xxviii-xxxii (reprinting Royal Charter of 1557).

118 Lee, supra note 53, at 322; see Star Chamber Decree for Orders in Printing, 1586, 28 Eliz., §§ 6-7; see also 1 WILliam F. PATRY, PATRY ON COPYRIGHT § 1:6 (2007) ("The Company was granted the power to search printing and bookselling establishments, to seize illegally printed books, and to imprison violators."); Raymond Astbury, The Renewal of the Licensing Act in 1693 and lts Lapse in 1695, 33 LIBRARY 296, 296 (1978).

119 Printing Act of 1643, reprinted in 1 ACTS AND ORDINANCES, supra note 112, at 185.

${ }_{120}$ Printing Act of 1662, supra note 112 (emphasis added).

121 Id. $\S \S 11-12$. The Act hoped to achieve this reduction in number of presses by the eventual deaths of the then-living printers that could own presses, leaving only twenty printers in England who each could own only two presses. Id. 
the Act attempted to stop copyright infringement and other unauthorized publications. The rationale was as simple as it was pernicious: without the technology, the general public could not use the press to make unauthorized printings-or any printings at all. ${ }^{122}$

Just as with the Crown's efforts to disarm the populace of guns, the Crown's efforts to limit and even destroy printing presses sparked an intense backlash among the people. ${ }^{123}$ The protest galvanized around the concept of "the freedom of the press," which eventually helped to secure the demise of the Printing Acts. ${ }^{124}$ In its place, Parliament later passed the Statute of Anne in 1710, the first copyright act in England. ${ }^{125}$ Besides limiting the terms of copyrights for authors, the Statute of Anne is significant for what it did not do: it "did not attempt to limit the number of printing presses or printers, or otherwise regulate the presses as was the case under the Printing Acts." 126

Thus, a crucial part of the freedom of the press in England was the shift from the regime of press controls under the Printing Acts, along with the Stationers' Company's physical control over the presses themselves, ${ }^{127}$ to the less restrictive alternative of a copyright system that had no power to limit the technology of the printing presses whatsoever. ${ }^{128}$ Even though one of the express purposes of the Statute of Anne was to combat piracy or copyright infringement, the Act did not replicate the press restrictions of the past. ${ }^{129}$ In short, there were no more technology limits. The printing presses became free.

122 The Crown sought control over the printing presses primarily for censorship reasons, e.g., to stop perceived seditious or heretical writings, whereas the Stationers' Company exercised its power over the presses in order to stop the "piracy" of its works. Over time, as the Crown diminished in power, the anti-piracy rationale predominated over the censorship rationale in the restrictions on the printing press. See Craig W. Dallon, The Problem with Congress and Copyright Law: Forgetting the Past and lgnoring the Public Interest, 44 SANTA CLARA L. REV. 365, 395-99 (2004).

${ }^{123}$ Lee, supra note 53 , at 323-25.

124 Id. at 325-26.

125 An Act for the Encouragement of Learning, by Vesting the Copies of Printed Books in the Author's or Purchasers of Such Copies, During the Times Therein Mentioned, 1710, 8 Ann., c. 19 [hereinafter Statute of Anne].

${ }^{126}$ Lee, supra note 53, at 327.

127 John Feather, From Rights in Copies to Copyright: The Recognition of Authors' Rights in English Law and Practice in the Sixteenth and Seventeenth Centuries, 10 CARDOZO ARTS \& ENT. L.J. 455, 463 (1992) ("For more than a century after the invention of printing, it was the printers, with their command of the limited technical facilities for book production, who controlled the trade .... [I]t was the printers who dominated the Stationers' Company in the first ten or fifteen years after its Charter was granted."). The only other individuals outside of the Stationers' Company who could own presses in England were those who had obtained printing patents, under the royal prerogative, directly from the Crown. See id. at 456; see also MARK ROSE, AUTHORS AND OWNERS: THE INVENTION OF COPYRIGHT 12 (1993).

${ }^{128}$ Lee, supra note 53, at 327-30.

129 Statute of Anne, supra note 125, at preamble (recognizing that "printers, booksellers, and 
In his Commentaries, Blackstone recognized the monumental significance of the demise of the Printing Acts, which, as he described, had "limited the number of printers, and of presses each should employ, and prohibited new publications unless previously approved by proper licensers." ${ }^{130}$ Once these restrictions on the press were removed, "'the press became properly free ... and has ever since so continued.",131 St. George Tucker, writing annotations to Blackstone in the early United States, made similar observations on the historical connection between the end of the several restrictions of the Printing Acts and the beginning of the freedom of the press. ${ }^{132}$

The English history of press restrictions informed the Framing of the Free Press Clause, and the debate between Anti-Federalists and the Federalists. ${ }^{133}$ The debate over the necessity (or not) of a free press clause followed a very similar terrain as the debate over the right to bear arms, with the Federalists arguing that a free press clause was unnecessary because Congress had no express power to regulate the press. ${ }^{134}$ That stock argument did not persuade the Anti-Federalists, who pointed specifically to the Copyright Clause as a possible basis for Congress to restrict the press. ${ }^{135}$ For example, Robert Whitehall of Pennsylvania argued:

Tho[ugh] it is not declared that Congress have a power to destroy the liberty of the press; yet, in effect, they will have it. ... They have a power to secure to authors the right of their writings. Under this, they may license the press, no doubt; and under licensing the press, they may suppress it. ${ }^{136}$

The proposal for a free press clause was thus defended as necessary to limit Congress's ability to use copyright under the Copyright Clause in a way to restrict the printing press. ${ }^{137}$ In response, the Federalists argued that the Copyright Clause only gave

other persons have of late frequently taken the liberty of printing, reprinting, and publishing... book and other writings, without the consent of the authors or proprietors of such books and writings, to their very great detriment, and too often to the ruin of them and their families").

130 Lee, supra note 53, at 329 (quoting WILLIAM BLACKSTONE, 4 COMMENTARIES *152). Blackstone's view was shared by J.L. de Lolme, in THE CONSTITUTION OF ENGLAND 288 (T. Spilsbury ed., 1775) (noting that after the "prohibitions" of the Printing Acts were rejected in 1694, "the freedom of the press . . . was finally established").

131 Lee, supra note 53, at 329 (quoting WILLIAM BLACKSTONE, 4 COMMENTARIES *152); see, e.g., Star Chamber Decree for Orders in Printing, 1586, 28 Eliz., §§ 1-3; Printing Act of 1662, supra note $112, \S \S 11-12$.

1321 TUCKER, supra note 71, at app. 12.

133 Lee, supra note 53, at 331-39.

134 Id. at 332-33.

135 Id. at 334.

1362 THE DOCUMENTARY HISTORY OF THE RATIFICATION OF THE CONSTITUTION: RATIFiCation of the Constitution by THE States, PENNSYlvania 454 (Merrill Jensen ed., 1976) (first emphasis added).

137 Id. 
Congress the limited power to secure copyrights to authors for limited times similar to the Statute of Anne in England. As James Iredell (who would later serve as a justice on the first Supreme Court) explained:

The liberty of the press is always a grand topic for declamation, but the future Congress will have no other authority over this than to secure to authors for a limited time an exclusive privilege of publishing their works. This authority has been long exercised in England, where the press is as free as among ourselves or in any country in the world; and surely such an encouragement to genius is no restraint on the liberty of the press, since men are allowed to publish what they please of their own, and so far as this may be deemed a restraint upon others it is certainly a reasonable one, and can be attended with no danger of copies not being sufficiently multiplied, because the interest of the proprietor will always induce him to publish a quantity fully equal to the demand. Besides, that such encouragement may give birth to many excellent writings which would otherwise have never appeared. If the Congress should exercise any other power over the press than this, they will do it without any warrant from this constitution, and must answer for it as any other act of tyranny. ${ }^{138}$

But Iredell's argument failed to mollify the Anti-Federalists, who were successful in securing the Free Press Clause in the Bill of Rights.

Legal scholars have long overlooked this connection between the Free Press Clause and the Copyright Clause. Professors Patterson and Joyce are right to suggest that the Free Press Clause was "the companion-piece of the Copyright Clause."139 Indeed, the Free Press Clause was more than just a companion-it was the chaperone for the Copyright Clause, establishing limits on what the Copyright Clause can do. The Free Press Clause forbids Congress from resurrecting technology restrictions of the kind imposed under the Printing Acts in England. ${ }^{140}$

138 JAMES IREDELL, OBSERVATIONS ON GEORGE MASON'S OBLIGATIONS TO THE FEDERAL CONSTITUTION (1788), reprinted in PAMPHLETS ON THECONSTITUTION OF THE UNITED STATES 360-61 (Paul Leicester Ford ed., 1968) (emphasis added).

139 L. Ray Patterson \& Craig Joyce, Copyright in 1791: An Essay Concerning the Founders' View of the Copyright Power Granted to Congress in Article I, Section 8, Clause 8 of the U.S. Constitution, 52 EMORY L.J. 909, 946 (2003).

${ }_{140}$ In this respect, the Free Press Clause may be slightly different from the design of the Second Amendment. Unlike the Second Amendment, the Free Press Clause must be read in direct relation to and as a direct limit on another clause of the Constitution, namely, the Copyright Clause, in order to understand one of the Free Press Clause's core protections. One could argue that the Second Amendment also must be read in direct relation to the Militia Clauses. See U.S. CoNST. art. I, \& 8, cls. 15 \& 16; United States v. Miller, 307 U.S. 174, 178 


\section{The Heller Court's Analogies Between the Second Amendment and the Free Speech and Free Press Clauses}

Lest there be any lingering doubt about the connection between the Second Amendment and the Free Press Clause, the Heller decision itself provides numerous analogies to both the Free Press Clause and the First Amendment. Indeed, on no less than six occasions in discussing the Second Amendment, the Heller Court drew a direct analogy to the First Amendment, including several times specifically to the Free Press Clause. ${ }^{141}$

For example, in explaining why examining the history of the right to bear arms in England was necessary, the Heller Court stated that "it has always been widely understood that the Second Amendment, like the First and Fourth Amendments, codified a pre-existing right." 142 And, in further describing the scope of the Second Amendment, the Court again pointed to the First Amendment for several direct analogies, all indicating similarities rather than differences between the two provisions:

Just as the First Amendment protects modern forms of communications, ... the Second Amendment extends, prima facie, to all instruments that constitute bearable arms, even those that were not in existence at the time of the founding. ${ }^{143}$

(1939). The Heller Court, however, did not view the connection to be as direct as the dissent did. Compare District of Columbia v. Heller, 128 S. Ct. 2783, 2799-2801 (2008) (majority opinion), with id. at 2831-32 (dissenting opinion). The slight difference from the design of the Second Amendment does not vitiate the argument for interpreting the Free Press Clause in a similar manner to the Court's analysis of the Second Amendment. Both clauses have an original, core protection dating back to the Framers that should be recognized and enforced.

Another complexity that the Second Amendment does not possess is that the Free Press Clause also is a companion to the Free Speech Clause. Although the Court has on a few occasions considered the intersection between the Copyright Clause and the Free Speech Clause or First Amendment more generally, Eldred v. Ashcroft, 537 U.S. 186, 219 (2003) ("The Copyright Clause and First Amendment were adopted close in time. This proximity indicates that, in the Framers' view, copyright's limited monopolies are compatible with free speech principles."); Harper \& Row, Publishers, Inc. v. Nation Enters., 471 U.S. 539, 558 (1985) ("[T]he Framers intended copyright itself to be the engine of free expression. By establishing a marketable right to the use of one's expression, copyright supplies the economic incentive to create and disseminate ideas."), the Court has yet to discuss or analyze the relationship between the Free Press and the Copyright Clauses, or the precise relationship between the Free Press and the Free Speech Clauses. The Free Press Clause protects a separate, but related right to the Free Speech Clause-while the latter protects expression itself, the former protects speech technologies from governmental restrictions, especially those imposed through copyright law. For a more complete exegesis of the relationship between the Free Press and the Free Speech Clauses, see Lee, supra note 53, at 339-51.

141 See Heller, 128 S. Ct. at 2791, 2797, 2799.

142 Id. at 2797.

143 Id. at 2791-92. 
The First Amendment contains the freedom-of-speech guarantee that the people ratified, which included exceptions for obscenity, libel, and disclosure of state secrets, but not for the expression of extremely unpopular and wrong-headed views. The Second Amendment is no different. ${ }^{144}$

There seems to us no doubt, on the basis of both text and history, that the Second Amendment conferred an individual right to keep and bear arms. Of course the right was not unlimited, just as the First Amendment's right of free speech was not.... Thus, we do not read the Second Amendment to protect the right of citizens to carry arms for any sort of confrontation, just as we do not read the First Amendment to protect the right of citizens to speak for any purpose. ${ }^{145}$

If those passages were not enough, the Heller Court also quotes approvingly from an 1825 Massachusetts Supreme Judicial Court opinion and an 1868 constitutional law treatise that make the direct analogy between the right to bear arms and the freedom of the printing press:

The liberty of the press was to be unrestrained, but he who used it was to be responsible in cases of its abuse; like the right to keep fire arms, which does not protect him who uses them for annoyance or destruction. ${ }^{146}$

The [Second Amendment] clause is analogous to the one securing the freedom of speech and of the press. Freedom, not license, is secured; the fair use, not the libellous abuse, is protected. ${ }^{147}$

144 Id. at 2821.

145 Id. at 2799 (internal citations omitted).

146 Id. at 2803 (quoting Commonwealth v. Blanding, 20 Mass. (3 Pick.) 304, 313-14 (1825)).

147 Id. at 2812 (quoting JOHN NORTON POMEROY, AN INTRODUCTION TO THE CONSTITUTIONAL LAW OF THE UNITED STATES 152-53 (Boston, Houghton Mifflin \& Co. 1868)). Comparing the right to bear arms and the freedom of the press apparently was not uncommon in the early 1800 s. See, e.g., H.P. NUGENT, AN ACCOUNT OF THE PROCEEDINGS HAD IN THE SUPERIOR COURT OFTHE TERRITORY OF ORLEANS, AGAINST THIERRY \& NUGENT FOR LIBELS AND CONTEMPT OF COURT 43 (Phila. 1810) ("It is true, said [Judge Francois Xavier Martin], the constitution secures the liberty of the press, but it likewise secures the liberty of keeping arms; now, as the liberty of keeping arms is not the liberty of killing or maiming whom we please, so is not the liberty of the press, the liberty of publishing libels."); REPORT OF THE TRIAL, TIMOTHY UPHAM VS. HILL \& BARTON FOR AN ALLEGED LIBEL, AT THE COURT OF 
These passages from the 1800 s, along with the Court's own analysis, suggest that the Court might apply the same or similar kind of interpretive method to determine the meaning of the Free Press Clause. The next Part explains why the Court should.

\section{IS HELLER RELEVANT to INTERPRETING THE FreE PRESS Clause?}

The Heller Court's several analogies between the First and Second Amendments notwithstanding, most legal commentators have not ever entertained a possible connection between the two amendments. The notable exception is L.A. Powe, whose provocative article in 1999 compared the two and suggested that First Amendment case law may be helpful in thinking about the Second Amendment. ${ }^{148}$ While suggestive, even Powe's article overlooked the historical connection between arms and presses at the time of the Framing. Although Powe's article has elicited very little response in legal scholarship over the years, Heller confirmed Powe's insight by making several analogies to the First Amendment. ${ }^{149}$ Not surprisingly, First Amendment

COMMON PLEAS, RoCKINGHAM COUNTY 74 (Concord, Hill \& Barton 1831) ("What is liberty of person?-liberty of speech? Are we not free? But have we a right to knock down and trample upon all whom we may dislike? ... We have, too, the right of bearing arms. And if we are not permitted to throw a brand into our neighbor's dwelling, or discharge our rifle upon the passers by in the street, we could as well complain of being enslaved, as to say the press is shackled, because it may not, by falsehood, assault the character of any and every citizen, when and where its conductors may choose.") (argument of lawyer Ichabod Bartlett). Thanks to Eugene Volokh for these examples.

148 See Powe, supra note 67, at 1313; cf. William Van Alstyne, The Second Amendment and the Personal Right to Arms, 43 DUKE L.J. 1236, 1240 (1994) ("The main reason there is such a vacuum of useful Second Amendment understanding, rather, is the arrested jurisprudence of the subject as such, a condition due substantially to the Supreme Court's own inertia - the same inertia that similarly afflicted the First Amendment virtually until the third decade of this twentieth century when Holmes and Brandeis finally were moved personally to take the First Amendment seriously (as previously it scarcely ever was).").

149 The only extended discussion of Powe's idea appears to have come in a student note in 2003. See David G. Browne, Note, Treating the Pen and the Sword as Constitutional Equals: How and Why the Supreme Court Should Apply Its First Amendment Expertise to the Great Second Amendment Debate, 44 WM. \& MARY L. REV. 2287 (2003); see also Calvin Massey, Guns, Extremists, and the Constitution, 57 WASH. \& LEE L. REV. 1095, 1128 (2000) (analogizing to First Amendment prior restraint cases in analyzing Second Amendment claims to gun licensing laws); Glenn Harlan Reynolds, A Critical Guide to the Second Amendment, 62 TENN. L. REV. 461, 478 (1995) (analogizing to free speech cases to understand the Second Amendment).

The conventional approach among First Amendment scholars is to discuss the regulation and design of speech technologies as free speech (or generic First Amendment) concerns. Practically no discussion is devoted to the historical relevance of the freedom of the press to restrictions on speech technologies, even in scholarship focusing on such technologies. See, e.g., Jack M. Balkin, The Future of Free Expression in a Digital Age, 36 PEPP. L. REV. 427, 442-44 (2009) (discussing the importance of innovation and the development of information 
scholars have already started citing and analyzing Heller in discussions of the First Amendment. ${ }^{150}$ This discussion is a start in the right direction, but it needs to go much further-and now in the opposite direction as well (considering the Second Amendment in understanding the First). This section lays out the reasons why the Supreme Court would benefit from consideration of Heller in analyzing the Free Press Clause with a similar approach in looking to text and history to identify a core protection of the Clause.

\section{A. Paucity of Case Law Interpreting the Free Press Clause}

One simple reason that Heller may provide helpful guidance for the Court in future cases involving the Free Press Clause is that the Free Press Clause stands today in many respects as the Second Amendment did pre-Heller. The precise meaning and historical origin of the Free Press Clause remain largely unexamined in the Court's jurisprudence. ${ }^{151}$ Although the Court has considered far more First Amendment cases than Second Amendment cases, the Court routinely analyzes First Amendment cases under the Free Speech Clause or, more generically, "the First Amendment" or the Free Speech and Free Press Clauses. ${ }^{152}$ Only a few cases stand or fall on the Free Press Clause alone, typically cases involving the rights of newspapers. ${ }^{153} \mathrm{My}$ aim is not

technology to free speech values). In short, the Free Press Clause is ignored. In this regard, I disagree with Jack Balkin's recent prediction that future policy debates "will increasingly shift to questions of design-both of institutions and technology - that are largely beyond judicial competence" and ones that will be left to "legislatures, administrative agencies, and technologists." Id. at 443-44. Balkin is right to suggest that technological design and innovation are gaining increasing importance in First Amendment debates in our digital age. In my view, however, the courts will have a vital role in these debates. For the best technology policy lies in the Constitution itself-the Free Press Clause and its protection for speech technologies. That clause, although long ignored, will become increasingly important, as will judicial review, as Congress attempts to enact more pieces of legislation that target or restrict speech technologies in the future.

150 See, e.g., 1 RodNey A. SMOLla, SMOLla \& NIMMER ON FrEedom OF SPEECH § $\$ 1: 1$, 1:2, 1:4 (2008); Posting of Eugene Volokh to the Volokh Conspiracy, http://volokh.com/ archives/archive_2008_08_10-2008_08_16.shtml\#1218485530/(Aug. 11, 2008, 17:37 EST).

151 The Court's most extensive historical analysis of the Free Press Clause is found in two concurring opinions, one by Justice Thomas and the other by the late Chief Justice Burger. See McIntyre v. Ohio Elections Comm'n, 514 U.S. 334, 359-60 (1995) (Thomas, J., concurring); First Nat'l Bank of Boston v. Bellotti, 435 U.S. 765, 796-802 (1978) (Burger, C.J., concurring).

152 See Lee, supra note 53, at 354 \& n.263.

153 See, e.g., Ark. Writers' Project, Inc. v. Ragland, 481 U.S. 221, 227-28 (1987) (holding that a differential tax on magazines versus newspapers violated the Free Press Clause); Minneapolis Star \& Tribune Co. v. Minn. Comm'r of Revenue, 460 U.S. 575, 582-83 (1983) (finding that a use tax on paper and ink for publications violated the Free Press Clause); Okla. 
to suggest that these cases were wrongly decided, but instead, to argue that most of the Court's cases have missed the technological side to the Free Press Clause, not to mention one of the core abuses-the Crown's technology limits on the printing press-that the Clause was designed to prevent. The Free Press Clause is not simply a no prior restraint clause. Nor is it a clause only for newspapers. Given the paucity of case law analyzing the Free Press Clause, the Court has a similar opportunity to undertake a more exhaustive review of the Clause's origins as it did for the Second Amendment in Heller.

As Akhil Amar and Cass Sunstein have both suggested (Amar favorably, Sunstein only descriptively), originalism may be more likely an interpretive move when a court

Publ'g Co. v. Dist. Court, 430 U.S. 308, 311-12 (1977) (holding that a trial court order against newspapers publishing the name or picture of a minor involved in a proceeding violated the Free Press Clause); Neb. Press Ass'n v. Stuart, 427 U.S. 539, 570 (1976) (holding that a court order against press disclosures in a criminal case was a prior restraint in violation of the Free Press Clause); Lovell v. City of Griffin, 303 U.S. 444, 451-52 (1938) (finding that an ordinance prohibiting leafleting without a permit violated the Free Press Clause); Grosjean v. Am. Press Co., 297 U.S. 233, 251 (1936) (finding that a state tax on advertisements affecting newspapers violated the Free Press Clause); Near v. Minnesota, 283 U.S. 697, 722-23 (1931)(holding that a state law allowing injunctions against future "malicious, scandalous and defamatory" newspaper publications was a prior restraint in violation of the Free Press Clause).

The Court's more typical approach, particularly in modern times, is to avoid decisions based solely on the Free Press Clause. See, e.g., McConnell v. FEC, 540 U.S. 93, 107 (2003) (rejecting for lack of standing a free press challenge to the Bipartisan Campaign Reform Act of 2002); Watchtower Bible \& Tract Soc'y of N.Y., Inc. v. Village of Stratton, 536 U.S. 150, 164 (2002) (finding that a permit law for door-to-door advocacy violated the First Amendment); Rosenberger v. Rector \& Visitors of Univ. of Va., 515 U.S. 819, 845 (1995) (denying funding to a Christian student newspaper violated the Free Speech Clause); McIntyre, 514 U.S. at 357 (holding that a state prohibition on anonymous leafleting violated the freedom of speech under the First Amendment); Turner Broad. Sys., Inc. v. FCC, 512 U.S. 622, 636 (1994) ("Cable programmers and cable operators engage in and transmit speech, and they are entitled to the protection of the speech and press provisions of the First Amendment."); FCC v. League of Women Voters, 468 U.S. 364, 399-400 (1984) (holding that a federal ban on editorializing by noncommercial educational broadcasting stations violated the First Amendment); Landmark Comm'ns, Inc. v. Virginia, 435 U.S. 829, 838 (1978) (holding that a state law forbidding disclosure of information derived from proceedings before a state commission violated the freedom of speech and freedom of the press); Red Lion Broad. Co. v. FCC, 395 U.S. 367, 394 (1969) ("To condition the granting or renewal of licenses on a willingness to present representative community views on controversial issues is consistent with the ends and purposes of those constitutional provisions forbidding the abridgment of freedom of speech and freedom of the press.”); N.Y. Times Co. v. Sullivan, 376 U.S. 254, 264 \& n.4 (1964) (recognizing that an actual malice standard of liability for defamation is required under the Free Speech and Free Press Clauses); Talley v. California, 362 U.S. 60, 63-64 (1960) (holding that an ordinance prohibiting anonymous handbills violated the freedom of speech and freedom of the press); Schneider v. New Jersey, 308 U.S. 147, 165 (1939) (finding that an ordinance against leafleting violated the freedom of speech and freedom of press). 
is interpreting a provision with very few precedents. ${ }^{154}$ By contrast, the possible relevance of Heller to free press cases would be greatly diminished, if not foreclosed, if the Court had already developed a long line of free press case law defining its protection. In such a case, stare decisis may well counsel against considering a new approach to the area of law, particularly if it conflicted with the well-established precedent. That is not the case, however, with the Free Press Clause, which continues to remain overshadowed by the Court's free speech (or "First Amendment") analysis.

\section{B. Textual and Historical Parallels Between "Arms" and "Press"}

The major substantive reason for considering Heller in interpreting the Free Press Clause is the striking textual and historical parallels between the right to bear arms and the freedom of the press. As detailed in greater depth above in Part II, the right to bear arms and the freedom of the press are tied historically and textually. ${ }^{155}$

Indeed, of all the provisions in the Constitution, the Framers included only two for express protection of a technology. ${ }^{156}$ Yet the two technologies they specified for express protection-arms and the printing press-were probably the two most revolutionary to the Framing generation. The latter was essential to spreading political ideas, while the former, to physically defending oneself. Both protected people from tyranny. ${ }^{157}$ Both were instrumental to the American revolution. ${ }^{158}$ It is not hard to imagine why the Framers singled out only these two technologies for constitutional protection. Madison and his contemporaries spoke about the two rights in the same breath, and often in similar ways describing them separately as private rights, the "palladium of liberty," and necessary or essential to a "free state." 159 Not surprisingly, several state constitutions contemporaneous to the Framing had free press clauses that were drafted similar to the Second Amendment's unique construction in the Bill of Rights-i.e., with a justification or prefatory clause. ${ }^{160}$ Early drafts of these two amendments to the Constitution also contained similarities in construction, including placement consecutively. ${ }^{161}$

154 See Amar, supra note 41, at 179 ("The first big opinion in a field, if done well, can lay out the first principles of constitutional text, history, and structure, and an originalist/textualist is well suited to that task."); Sunstein, supra note 4 ("In answering that question [of first impression], many judges might be drawn to the original understanding even if they would not consider it, or would not give it a great deal of weight, if they were writing on an unclean slate."); id. at 250 ("Originalism seems to have more appeal when doctrine is not developed, but the Court has rarely spoken in originalist terms even when doctrine barely exists.").

155 See supra Part II.

156 See supra notes 44-52 and accompanying text.

157 See supra notes 68-78 and accompanying text.

158 See supra note 76 and accompanying text.

159 See supra notes 54-57, 68-73 and accompanying text.

160 See supra notes $90-96$ and accompanying text.

${ }^{161}$ See supra notes $64-67,94-99$ and accompanying text. 
What the text suggests the history confirms. The long history of abuses of the British Crown in restricting these two technologies from the people shows the clear connection between the right to bear arms and freedom of the press. ${ }^{162}$ The Framers loathed the Crown's attempts to deprive the people of these technologies as a way to quell political and religious dissent. ${ }^{163}$ Both clauses sought to end the core abuse of the government depriving the people of technologies, whether arms or presses.

\section{Identifying the Core Protections of the Free Press Clause}

Another reason that the Heller decision is appropriate for the Court to consider in free press cases is that Heller's approach is, in fact, very similar to how the Court has already discussed the Free Press Clause, in those relatively few cases in which the history of the Free Press Clause has come up. The Supreme Court has recognized that a prepublication licensing requirement-a prior restraint-is a violation of the First Amendment, ${ }^{164}$ reminiscent of the history of abuses of the British Crown under the notorious Printing Acts. ${ }^{165}$ As Justice Scalia explained:

The First Amendment's guarantee of "the freedom of speech, or of the press" prohibits a wide assortment of government restraints upon expression, but the core abuse against which it was directed was the scheme of licensing laws implemented by the monarch and Parliament to contain the "evils" of the printing press in 16th-and 17th-century England. The Printing Act of 1662 had "prescribed what could be printed, who could print, and who could sell."166

It is striking that Justice Scalia speaks of a "core abuse," which is reminiscent of the discussion of "core protection" in Heller. Elsewhere in its First Amendment jurisprudence, the Court has sought to protect its "core protections," in a manner strikingly

162 See supra Part II.B.1.

163 See supra notes 107-08, 133-40 and accompanying text.

164 See, e.g., Staub v. City of Baxley, 355 U.S. 313, 322 (1958) ("It is settled by a long line of recent decisions of this Court that an ordinance which, like this one, makes the peaceful enjoyment of freedoms which the Constitution guarantees contingent upon the uncontrolled will of an official-as by requiring a permit or license which may be granted or withheld in the discretion of such official-is an unconstitutional censorship or prior restraint upon the enjoyment of those freedoms.").

${ }^{165}$ Lee, supra note 53, at 320-21.

166 Thomas v. Chi. Park Dist., 534 U.S. 316, 320 (2002) (emphasis added) (citations omitted). 
similar to the approach in Heller. ${ }^{167}$ (Likewise, for other clauses, the Court has sought to identify and protect their "core protections."

Although Justice Scalia correctly describes one core abuse of the Printing Acts in the prepublication licensing (or prior restraint) scheme, another core abuse was the restriction on the technology of the printing press itself. As Blackstone described in his Commentaries, the Printing Acts "limited the number . . of presses."169 Indeed, the Acts attempted to decrease the total number of printing presses allowed in England: nonconforming presses were considered contraband and subject to destruction by the Stationers' Company, which held not only legal control over the copyrights to works, but also physical control over the permitted printing presses. ${ }^{170}$ The technological restrictions in the Printing Acts were designed, in other words, to facilitate the monopoly over publishing held by the Stationers' Company, the de facto copyright holders of the period. As copyright historian Mark Rose recounts, "censorship and trade regulation became inextricable, and this was a marriage that was to endure until the passage of the Statute of Anne in 1710."171

\section{Caveats}

This Part has attempted to present the case, at least a prima facie one, for considering Heller and its framework for the Second Amendment as persuasive authority in interpreting the Free Press Clause. Several caveats are in order.

167 See, e.g., McIntyre v. Ohio Elections Comm'n, 514 U.S. 334, 346 (1995) (“[T]he category of speech regulated by the Ohio statute occupies the core of the protection afforded by the First Amendment . . . ." (emphasis added)); Phila. Newspapers, Inc. v. Hepps, 475 U.S. 767, 778 (1986) (recognizing that "speech of public concern is at the core of the First Amendment's protections" (emphasis added)); FCC v. League of Women Voters of Cal., 468 U.S. 364, $380 \mathrm{n} .13$ (1984) (observing that the case involved "expression that is at the core of First Amendment protections" (emphasis added)); see also FEC v. Wis. Right to Life, 127 S. Ct. 2652, 2676 (2007) (Scalia, J., concurring in part and in judgment) ("The [Buckley v. Valeo] Court began with the recognition that contributing money to, and spending money on behalf of, political candidates implicates core First Amendment protections, and that restrictions on such contributions and expenditures 'operate in an area of the most fundamental First Amendment activities."' (emphasis added) (quoting Buckley v. Valeo, 424 U.S. 1 (1976))).

168 See, e.g., United States v. Patane, 542 U.S. 630, 637 (2004) (plurality opinion) ("[T] core protection afforded by the Self-Incrimination Clause is a prohibition on compelling a criminal defendant to testify against himself at trial."); Shaw v. Reno, 509 U.S. 630, 642 (1993) ("Laws that explicitly distinguish between individuals on racial grounds fall within the core of that prohibition [under the Equal Protection Clause]."); California v. Green, 399 U.S. 149, 157 (1970) ("Our own decisions seem to have recognized at an early date that it is this literal right to 'confront' the witness at the time of trial that forms the core of the values furthered by the Confrontation Clause ....").

169 BLACKSTONE, supra note 73 , at *152.

170 Lee, supra note 53, at 321-23; see also supra notes 115-19 and accompanying text.

171 RoSE, supra note 127, at 13. 


\section{On History and Text}

As with any historical account of the Framing, my historical discussion of (i) how the Free Press Clause developed partly in response to the Copyright Clause and (ii) how the freedom of the press relates to the right to bear arms cannot be proven with certainty. I have tried to discern the most plausible understanding of the "freedom of the press" based on the text of the Constitution and the historical materials discussing the concept in seventeenth-century England and then later in the early Republic. Although not definitive, the historical evidence on the connection between the Free Press and Copyright Clauses is, in my view, weighty. Several Framers and their contemporaries spoke for or against the need for the Free Press Clause specifically in relationship to copyright or the Copyright Clause. ${ }^{172}$ The history of copyright and the freedom of the press in England, which informed the Framers, confirms the close connection between the freedom of the press and copyright. ${ }^{173}$ While the amount of historical materials drawing a connection between the freedom of the press and the right to bear arms may be more modest, it is significant that Madison and several of his contemporaries commonly referred to both in the same breath while discussing individual rights. ${ }^{174}$

While I have stressed the textual similarities, a few textual differences are worth mentioning. The First Amendment speaks of a "freedom," while the Second Amendment speaks of a "right," although it is not clear what, if any, significance to attribute to the difference in wording. ${ }^{175}$ Given the parallel construction in earlier drafts of the Bill of Rights equating the freedom of the press and the right to bear arms both as individual rights that "shall not be infringed," the Framers likely understood "freedom" and "right" as synonymous in the Bill of Rights. ${ }^{176}$ Also, while I have made modest note of the consecutive placement of the two clauses, one should not read too much into the placement. There are multiple clauses, not just the Free Press Clause, in the First Amendment, and that the Framers chose not to include the freedom of the press and the right to bear arms in the very same amendment provides some reason to question treating them in a completely equivalent manner. ${ }^{177}$

\section{On Constitutional Interpretation}

Of course, the Free Press Clause is independent of the Second Amendment and serves its own purpose. It would be foolish to argue that the Court should adopt the

172 See supra notes $135-38$ and accompanying text.

${ }_{173}$ See supra Part II.B.2.

174 See supra notes 54-57 and accompanying text.

175 Tushnet, supra note 41 (manuscript at 5).

176 Proceedings of the House of Representatives, Aug. 24, 1789, reprinted in THE ORIGIN OF THE SECOND AMENDMENT, supra note 63, at 706-07.

${ }^{177}$ For further discussion of the possible weight to give adjoining or non-adjoining clauses in the Constitution from an intratextualist view, see Amar, supra note 80, at 765, 796. 
identical approach, jot-for-jot, for both clauses, or that the precedents interpreting one clause are somehow direct precedent for the other clause. My argument is not that the Court should apply a type of "Second Amendment" analysis to the Free Press Clause, or that Heller should be read as a Free Press Clause precedent. Nor am I suggesting that the Court should abandon its existing First Amendment jurisprudence, or go back to the antiquated (common law) view of its freedoms as protecting only against prior restraints. Instead, I argue that Heller can provide a helpful reference point for the Court when it considers restrictions on technologies under the Free Press Clause. Such an approach is particularly useful in reviewing governmental restrictions on technology today that are analogous to a core abuse of the British Crown that concerned the Framers, such as, paradigmatically, the government depriving the people of guns or speech technologies.

Finally, I am not advocating for the adoption of "originalism" as a general or exclusive matter in interpreting the Constitution. That issue has been the topic of intense debate among constitutional law scholars, which goes well beyond the scope of this Article. ${ }^{178}$ The Court's own First Amendment jurisprudence-with different levels of scrutiny for content-based versus content-neutral regulations-could hardly be called originalist today. ${ }^{179}$ My goal here is not to defend originalism as a general theory of interpretation. Nor is it to jettison the Court's First Amendment jurisprudence. Instead, it is to show that the history of the Free Press Clause is important to understanding its meaning, especially because the case law is so underdeveloped today. Although history is often contestable, and lawyers and judges may not be the best historians by certain academic standards, ignoring history in interpreting the Constitution is even worse. As Professor Tribe aptly noted, "it would be hard to find any school of thought about the interpretation of constitutional language or structure that would dismiss history's claims as simply beside the point."180

\section{DOES HELLER SHOOT DOWN CONGRESS'S ATTEMPTS TO RESTRICT SPEECH TECHNOLOGIES THROUGH COPYRIGHT LAW?}

This final Part examines the practical importance of Heller for copyright laws that attempt to restrict speech technologies. Applying an approach similar to Heller to interpret the Free Press Clause, this Part examines three copyright restrictions of speech technologies: (i) the Audio Home Recording Act of 1992 (AHRA), (ii) the proposed "broadcast flag" bill, and (iii) the anti-circumvention provision of the Digital Millennium Copyright Act of 1992 (DMCA). Under this approach, AHRA and the "broadcast flag" bill both likely violate a core protection of the Free Press Clause by

${ }^{178}$ For a recent symposium on originalism, see Symposium, Symposium Essays on Originalism, 31 HARV. J.L. \& PUB. POL'Y 871 (2008).

${ }^{179} C f$. Tushnet, supra note 41 (manuscript at 8) (discussing prior restraint understanding).

180 TRIBE, supra note 81 , at 66. 
banning certain speech technologies that can be used for self-expression, whereas the DMCA probably passes muster.

\section{A. The Heller Framework and the Core Protection of the Second Amendment}

Although Heller stopped short of providing a definitive test for the Second Amendment, it did suggest a broad outline of how the Court might review gun control laws in the future. The framework can be characterized as follows: (i) Does the instrument restricted fall within the scope of protected "arms" under the Second Amendment, and (ii) if so, does the governmental restriction in question violate a core protection of the Amendment (as historically or originally understood), such as the right of citizens "to use arms in defense of hearth and home"? ${ }^{181}$

\section{Types of Arms Protected by the Second Amendment}

First, there is the threshold question of whether the weapon in question falls within the Second Amendment right. The Heller Court indicated that the Second Amendment extends "prima facie, to all instruments that constitute bearable arms," including modern weapons that did not exist at the time of the Framing. ${ }^{182}$ However, interpreting its decision in Miller, the Court suggested in dictum that a weapon (such as a sawed-off shotgun) does not fall within the scope of the Second Amendment if it is "not typically possessed by law-abiding citizens for lawful purposes, such as short-barreled shotguns." 183 The weapons must be "in common use at the time," able to be used at home, and not "dangerous and unusual weapons." 184

Applying this test, the Court easily found that handguns fall within the ambit of the Second Amendment: "handguns are the most popular weapon chosen by Americans for self-defense in the home, and a complete prohibition of their use is invalid."185

\section{The Core Protection(s) of the Second Amendment}

The second inquiry is whether the restriction or law in question impermissibly restricts the Second Amendment right to bear arms, assuming the weapon falls within the right. For this question, the Court declined to articulate a specific level of scrutiny. ${ }^{186}$

Instead, analogizing to free speech protections, the Court suggested that there is a "core protection" embodied in the Second Amendment that "takes out of the hands

\footnotetext{
181 District of Columbia v. Heller, 128 S. Ct. 2783, 2821 (2008).

182 Id. at 2792.

${ }^{183}$ Id. at 2816 (emphasis added).

${ }^{184}$ Id. at 2817.

185 Id. at 2818.

${ }^{186}$ Id. at 2821 .
} 
of government-even the Third Branch of Government-the power to decide on a case-by-case basis whether the right is really worth insisting upon." 187 Thus, "whatever else it leaves to future evaluation, it surely elevates above all other interests the right of law-abiding, responsible citizens to use arms in defense of hearth and home." Thus, once a core protection is identified, government restrictions that interfere with the individual's ability to exercise her rights within that core are unconstitutional.

The Court did acknowledge, however, it will likely have to determine in the future how the historical exceptions to the right to bear arms (such as denials of gun ownership to felons) fit in. ${ }^{189}$ The Court stopped short of articulating a test for how exceptions to the Second Amendment right should be analyzed. ${ }^{190}$ Lower courts have accepted the historical exceptions noted in Heller as valid exceptions to the Second Amendment right, and have begun to judge the validity of other exceptions by comparing them to Heller's noted historical exceptions. ${ }^{191}$

Applying its "core protection" approach, the Court easily found unconstitutional both (i) D.C.'s gun control law banning gun possession in the home (by disallowing registration), and (ii) D.C.'s law requiring firearms in the home to "be disassembled or bound by a trigger lock at all times, rendering them inoperable." ${ }^{\prime 192}$ Both provisions violated the core protection of the Second Amendment in preserving the right of the people to use guns in the home for self-defense.

\section{B. Proposed Framework: Core Protections of the Free Press Clause}

For the reasons explained above, the general interpretive method of Heller-in looking to the text and history of the Second Amendment to determine its original meaning and "core protection" consistent with the Framing era-provides a helpful mode of analysis for understanding the Free Press Clause. ${ }^{193}$

The basic framework for the Free Press Clause is: (i) Does the speech technology restricted fall within the protection of "press" under the Free Press Clause, and (ii) if so, does the governmental restriction in question violate a core protection of the Amendment (as historically or originally understood) that should not be subject to interest-balancing or case-by-case analysis. ${ }^{194}$

If a law violates a core protection of the Free Press Clause, then the restriction is per se unconstitutional. The whole point of Justice Scalia's admonition in Heller is

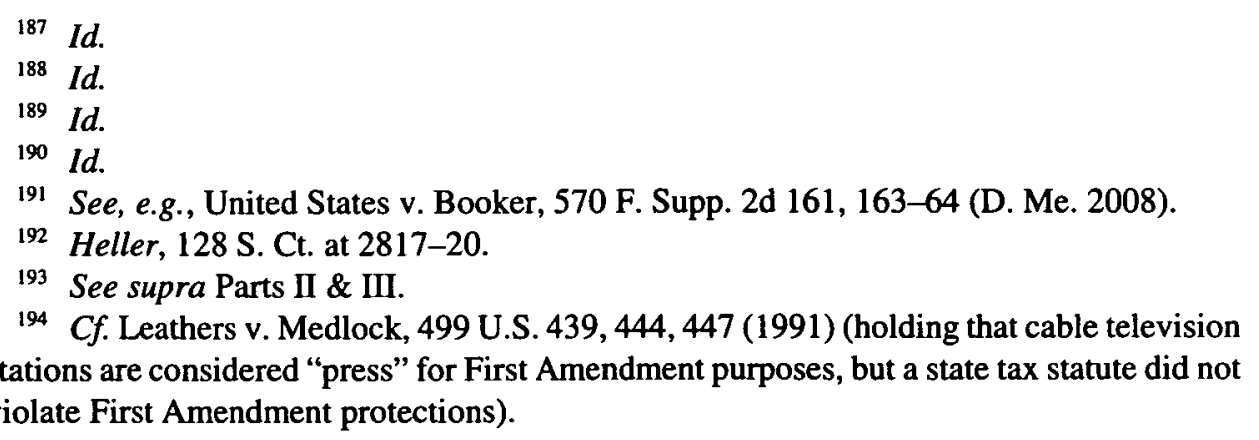


to keep the core protection immune from interest-balancing, or case-by-case analysis. ${ }^{195}$ However, if the restriction does not violate a core protection, the Court should consider whether the restriction nevertheless imposes a burden on speech that can withstand the relevant First Amendment scrutiny under the Court's established precedents. ${ }^{196}$

\section{Types of Speech Technologies Protected by Free Press Clause}

The Court has already taken a very expansive view of what speech technologies fall within the notion of the "press."197 "The press in its historic connotation comprehends every sort of publication which affords a vehicle of information and opinion." 198 For example, the Court has stated that "moving pictures, like newspapers and radio, are included in the press whose freedom is guaranteed by the First Amendment." 199 Add to the list both cable TV and the Internet. ${ }^{200}$ As the Heller Court itself reminded, "the First Amendment protects modern forms of communication." ${ }^{201}$ Although these several examples of speech technologies were all revolutionary at one time, the technologies can be as mundane as loud speakers and still fall within the First Amendment's ambit. ${ }^{202}$

195 See Heller, $128 \mathrm{~S}$. Ct. at 2821. One could imagine also recognizing a category of "historical exceptions" to the Free Press Clause right in a fashion similar to how the Court recognized for the Second Amendment. However, I doubt this category is particularly relevant or useful for speech technologies because "historical exceptions" do not appear to have arisen in this context. To my knowledge, historically, people were not deprived of or disqualified by law from owning a printing press due to a felony conviction or other factors. It is interesting to note that women participated in the print business in the early $1800 \mathrm{~s}$. See California Historical SocietylExhibits/EventsIPast Exhibits, Women in Printing \& Publishing in California: 1850-1940, http:/www .californiahistoricalsociety.org/exhibits/past_exhibits/ women/ (last visited Apr. 21, 2009). Except for perhaps the licensing of the radio spectrum, see Red Lion Broad. Co. v. FCC, 395 U.S. 367, 390 (1969)-an approach that is the subject of mounting and intense criticism, see Christopher S. Yoo, The Rise and Demise of the Technology-Specific Approach to the First Amendment, 91 GEO. L.J. 245, 266-306 (2003)the government has not historically or typically attempted to control or restrict ownership of speech technologies (as has been the case with guns). Therefore, I think it is appropriate to follow a different approach than Heller on the issue of exceptions.

196 To borrow Randy Barnett's description, when the original meaning does not address the issue with sufficient specificity (constitutional interpretation), the court must nevertheless engage in constitutional construction "to adopt a construction of the text that is consistent with its original meaning but not deducible from it." BARNETT, supra note 29, at 121 .

197 Lovell v. City of Griffin, 303 U.S. 444, 452 (1938).

198 Id.

199 United States v. Paramount Pictures, Inc., 334 U.S. 131, 166 (1948).

200 See Reno v. ACLU, 521 U.S. 844, 870 (1997) (Internet); Turner Broad. Sys., Inc. v. FCC, 512 U.S. 622,639 (1994) (plurality opinion) (cable).

201 District of Columbia v. Heller, 128 S. Ct. 2783, 2791 (2008) (emphasis added).

See Saia v. New York, 334 U.S. 558, 559-60 (1948). 


\section{The Core Protection(s) of the Free Press Clause in Safeguarding Speech} Technologies

A core protection of the Free Press Clause is to protect speech technologiesespecially those that directly enable, like the printing press, the widespread dissemination of speech-from government restrictions through copyright law, such as (i) limits on the total number of speech technologies that can be made, sold, and distributed to the public, (ii) limits on the ownership of such technologies, or (iii) the remedial powers that enabled the confiscation and destruction of non-approved presses as contraband. ${ }^{203}$ Bans on speech technologies, such as a ban on unapproved printing presses, are the most constitutionally suspect.

This core protection of the Free Press Clause has, for too long, been overlooked. As I have explained in greater depth elsewhere, the freedom of speech and the freedom of the press protect two separate, but related rights-just as the Establishment and Free Exercise Clauses do in the First Amendment as well. "While the freedom of speech protects an individual's basic right of expression, the freedom of the press is meant to ensure that speech technologies are free of governmental control," especially restrictions effectuated under copyright law. ${ }^{205}$

Indeed, the debate over the Free Press Clause between the Anti-Federalists and Federalists centered specifically on the Copyright Clause, and whether copyright could be used to effectuate controls on the printing press in ways similar to the abuses of the Printing Acts in England. ${ }^{206}$ James Iredell, a leading Federalist from North Carolina and later Supreme Court Justice, argued that the Copyright Clause gave Congress "no other authority over this than to secure to authors for a limited time an exclusive privilege of publishing their works," similar to the limited form of copyright under the Statute of Anne in England. ${ }^{207}$ Yet that argument was not able to assuage the AntiFederalists and the fervor for protecting the freedom of the press expressly in the Bill of Rights. The Anti-Federalists feared that the Copyright Clause itself could be used as a power to restrict the press, a sentiment that was understandable given the many abuses of the Crown under the Printing Acts that served the copyright holders' interests in England. ${ }^{208}$ Though a Federalist, Madison eventually agreed that a Bill of Rights, including a free press clause, was necessary and offered the first proposal for the amendments in the First Congress. ${ }^{209}$ Later, Madison wrote of the necessity for the Free Press Clause: "the article of amendment, instead of supposing in Congress

\footnotetext{
203 See supra Part II.B.2.

204 Lee, supra note 53, at 339-51.

205 Id. at 351 (emphasis added).

206 Id. at 331-36.

207 IREDEL, supra note 138 , at 361.

208 See Lee, supra note 53, at 334; supra notes 134-38 and accompanying text.

209 See Richard LABUNSKI, JAMES MADISON AND THE STRUGGLe FOR THE BILL OF RIGHTS 191-92 (2006).
} 
a power that might be exercised over the press, provided its freedom was not abridged, was meant as a positive denial to Congress of any power whatever on the subject."210 Thus, the original meaning of the Free Press Clause included an overriding distrust of governmental restrictions on the technology of the printing press, especially those effectuated through copyright law or in the service of copyright holders.

That the Framers, at the urging of the Anti-Federalists, eventually felt the need to add the Free Press Clause to the Constitution indicates their uneasiness with the Copyright Clause, which was modeled in part on the Statute of Anne. ${ }^{211}$ Although the Statute of Anne did establish in England a less restrictive system of copyright that did not contain either the licensing requirement or the technology limits of the repressive Printing Acts, nothing in the Statute of Anne expressly forbade the Printing Acts from being resurrected and imposing licensing and technology restrictions in the future. ${ }^{212}$ The same could be said - and was said during the Framing —of the Copyright Clause. ${ }^{213}$ The Free Press Clause effectively filled that potential hole in the Copyright Clause by directly limiting Congress's power to restrict speech technologies through copyright law. ${ }^{214}$

\section{Do Congress's Attempts to Regulate Technologies Through Copyright Law Violate the Free Press Clause?}

The Supreme Court has yet to discuss this important part of the origin of the Free Press Clause, perhaps understandably. To date, the Supreme Court has not ever reviewed a free press or First Amendment challenge to a copyright restriction on a technology. ${ }^{215}$ However, the Court will likely entertain such a challenge in the near future. Congress has already restricted speech technologies through copyright law

210 JAMES MADISON, REPORT ON THE VIRGINIA RESOLUTIONS (Jan. 1800), reprinted in 5 THEFOUNDERs' CONSTITUTION 143 (Philip B. Kurland \& Ralper Lerner eds., 1987) (emphasis added).

211 Statute of Anne, supra note 125.

212 Id.

213 Lee, supra note 53, at 334.

214 See TUCKER, supra note 71, at app. 13 ("But although this negative establishment may satisfy the subjects of England, the people of America have not thought proper to suffer the freedom of speech, and of the press to rest upon an uncertain foundation, as the will and pleasure of the government.").

215 The Supreme Court in the Sony case skirted around the First Amendment problem of banning the video recorder under secondary liability in copyright law by recognizing the Sony safe harbor, which protects technologies that are capable of substantial noninfringing uses from being the basis for liability. Sony Corp. of Am. v. Universal City Studios, Inc., 464 U.S. 417, 442 (1984). Elsewhere, I have explained how the Sony safe harbor operates as a First Amendment safeguard within copyright law (analogous to fair use and the idea-expression dichotomy) in order to protect free press interests and the development of speech technologies. Lee, supra note 53 , at $370-79$. 
on a few occasions and is considering even further restrictions, although this development is a late twentieth-century phenomenon. For over two hundred years, dating back to the First Congress and the first Copyright Act, the traditional contours of our copyright laws avoided any direct restriction on speech technologies. ${ }^{216}$ That long-held tradition has begun to change, with intense lobbying of copyright industries to regulate technologies. Congress's increasing efforts to regulate speech technologies as a way to protect copyrights make it likely the Supreme Court will eventually have to consider a free press challenge to such a restriction. Below I apply the "core protection" analysis of the Free Press Clause to three different restrictions on speech technologies enacted or proposed by copyright holders in the past twenty years. The first two restrictions, AHRA and the broadcast flag, both likely violate a core protection of the Free Press Clause, while the third restriction, the DMCA's anti-circumvention provision, probably does not.

\section{Audio Home Recording Act of 1992}

Under the "core protection" framework of the Free Press Clause, the technology restriction under AHRA is very likely unconstitutional. Enacted in 1992 as a compromise between media and electronics industries over the digital audio tape (DAT), AHRA has had very little practical impact due to the failure of the DAT in the marketplace. Because there are so few cases involving AHRA or DAT technologies, it is not surprising that AHRA has never been challenged in a lawsuit as violating the Free Press Clause. ${ }^{217}$ Nonetheless, the question is worthy of consideration, even if for only academic reasons.

AHRA forbids the importation, manufacture, or distribution of any digital audio recording device that does not contain the Serial Copy Management System (SCMS), a system devised by copyright holders and the recording industry to prohibit unauthorized serial copying of copyrighted tapes. ${ }^{218}$ Although SCMS allows copies to be made from an original copyrighted tape on a DAT machine, people cannot copy from any of the copies because the SCMS does not permit serial copying, even if for legitimate purpose. ${ }^{219}$ AHRA does contain an exemption for "the noncommercial use by a consumer of such a [digital audio recording] device or medium for making

216 See Lee, supra note 53, at 350-53.

217 Indeed, no reported case discussing AHRA has ever involved the failed DAT technology (as opposed to later technologies not consisting of the DAT). See, e.g., A\&M Records, Inc. v. Napster, Inc., 239 F.3d 1004, 1024 (9th Cir. 2001) (stating that AHRA does not apply to “downloading of MP3 files to computer hard drives"); Recording Indus. Ass'n. of Am. v. Diamond Multimedia Sys., Inc., 180 F.3d 1072, 1081 (9th Cir. 1999) (holding that an MP3 player was not a digital audio recording device within scope of AHRA).

21817 U.S.C. $\$ 1002$ (2006).

219 See Hyangsun Lee, The Audio Broadcast Flag System-Can It Be a Solution?, 12 COMM. L. \& POL'Y 405, 453 (2007). 
digital musical recordings or analog musical recordings," but this exemption is undercut because it does not give technology developers the right to manufacture any digital audio recording devices that do not prevent serial copying. ${ }^{220}$

If we apply our proposed framework, AHRA likely violates a core protection of the Free Press Clause. First, tape recorders are clearly a form of speech technology that falls within the scope of the Free Press Clause. Tape recorders effectively function as a printing press for capturing and distributing sound and audio. Like the press, the recorders take speech and reproduce it mechanically for greater dissemination of the speech. Even before the DAT, tape recorders were commonly used in homes and businesses, including for legitimate purposes.

Second, AHRA transgresses a core protection of the Free Press Clause by banning a speech technology. AHRA uses copyright law to impose a complete ban on any non-complying digital audio recording device that does not implement the recording industry's own copyright control measures. ${ }^{221}$ The ban on the importation, manufacture, or distribution of any non-conforming digital audio recording device effectively gives the recording industry control over the design of an entire speech technology. Copyright holders can seek impoundment and destruction of any nonconforming device, not to mention damages. ${ }^{222}$

AHRA is thus the functional equivalent of the Printing Acts. Under AHRA, the prepublication licensing system and technology limits of the Printing Acts are effectively implanted into the make-up of the technology itself. SCMS operates as a technological Stationers' Company of sorts within the digital audio recording device itself, imposing controls over what expression can be reproduced by the technology. AHRA bans all digital tape technology not approved by copyright holders, reminiscent of how the Printing Acts banned unregistered or unapproved presses not controlled by the Stationers' Company.

On its face, AHRA's ban on non-conforming speech technologies violates a core protection of the Free Press Clause. People are deprived of digital audio technologies that can facilitate their self-expression, even potentially in ways that do not infringe any copyrights. To draw an analogy to Heller, the SCMS restriction on digital audio tapes functions like the "trigger lock" requirement for handguns found unconstitutional by the Supreme Court. Just as the trigger lock requirement did to guns, SCMS renders inoperable the serial copying of digital tapes on all digital audio tape technologies, regardless if the copying is for legitimate purpose, such as fair use or other valid forms of self-expression. ${ }^{223}$

22017 U.S.C. $\S 1008$.

221 Id. $\S 1002$.

${ }^{222}$ Id. $\S 1009(\mathrm{f}),(\mathrm{g})$.

${ }^{223}$ Cf. District of Columbia v. Heller, 128 S. Ct. 2783, 2817-18 (2008) (holding that a trigger lock requirement violates core protections of the Second Amendment). 


\section{Proposed "Broadcast Flag" Bill}

In 2002, Congress considered an even more sweeping technological mandate under the so-called "broadcast flag" bill proposed by then-Senator Ernest "Fritz" Hollings. ${ }^{224}$ Although the bill was abandoned due to intense opposition from the computer and consumer electronic industries, it is still useful to examine the bill, which the copyright industries may attempt to revive one day. ${ }^{225}$

Essentially, the "broadcast flag" bill sought to do the same sort of thing that AHRA attempted to do for the failed DAT technology-i.e., first, to require devices to contain prescribed technological measures to reduce copyright infringement facilitated by those devices, and then, second, to ban all non-conforming speech technologies. ${ }^{226}$ The "broadcast flag" bill was far more sweeping than AHRA and applied basically to every device or technology capable of playing digital content. ${ }^{227}$

Under the bill, all nonconforming devices or technologies made after the effective date of the law would be categorically banned. ${ }^{228}$ The bill incorporated the remedies from the provisions of the DMCA,${ }^{229}$ which recognize the power of the court to issue injunctions "on such terms as it deems reasonable to prevent or restrain a violation, but in no event shall impose a prior restraint on free speech or the press protected under the 1st amendment to the Constitution."230

One difficulty of analyzing the "broadcast flag" bill is that it left the key component-the actual "broadcast flag" or copyright control measure mandated-for future determination either by agreement of "representatives of digital media device manufacturers, consumer groups, and copyright owners" subject to the FCC rule-making process, or, failing such agreement, directly by FCC rule making. ${ }^{231}$ Essentially, the bill punted the most difficult issue.

Nonetheless, perhaps in an attempt to avoid potential constitutional problems of restricting all digital technologies, the bill included the following provision:

224 Consumer Broadband and Digital Television Promotion Act, S. 2048, 107th Cong. (2002).

225 See Joseph P. Liu, Regulatory Copyright, 83 N.C. L. REV. 87, 125 (2004).

227 Id. $\$ 5$ ("digital media device"). The bill defined "digital media device" as: any hardware or software that-

(A) reproduces copyrighted works in digital form;

(B) converts copyrighted works in digital form into a form whereby the images and sounds are visible or audible; or

(C) retrieves or accesses copyrighted works in digital form and transfers or makes available for transfer such works to hardware or software described in subparagraph (B).

Id. $\S 9$.

Id. $\$ 5$.

Id. $\$ 7$. 
(1) LIMITATIONS ON THE EXCLUSIVE RIGHTS OF COPYRIGHT OWNERS. In achieving the goal of promoting as many lawful uses of copyrighted works as possible, while preventing as much infringement as possible, the encoding rules shall take into account the limitations on the exclusive rights of copyright owners, including the fair use doctrine.

(2) PERSONAL USE COPIES. No person may apply a security measure that uses a standard security technology to prevent a lawful recipient from making a personal copy for lawful use in the home of programming at the time it is lawfully performed, on an over-the-air broadcast, premium or non-premium cable channel, or premium or non-premium satellite channel, by a television broadcast station (as defined in section 122(j)(5)(A) of title 17, United States Code), a cable system (as defined in section 111(f) of such title), or a satellite carrier (as defined in section 119(d)(6) of such title). ${ }^{232}$

It is doubtful that these provisions save the "broadcast" flag bill from being unconstitutional. The first provision is merely advisory: it advises that the eventual rule should "take into account" fair use and other limitations on the exclusive rights of copyright holders. "Take into account" does not necessarily mean "fully protect or preserve" the ability of people to engage in legitimate fair use or free speech activities. Secondly, the "personal use copy" is limited to lawful home copying of only programmed television content; it does not establish a general exception or right for all personal use copies on digital media devices, even if they are lawful and fall outside the scope of copyright. A large and growing amount of TV content, however, is now distributed on the Internet and would appear to fall outside the bill's exception for personal use copies.

Moreover, the FCC has already tried once - on its own initiative, which the D.C. Circuit invalidated as falling outside of the FCC's statutory authority-to devise a "broadcast flag" rule. ${ }^{233}$ That rule required a digital code to be "embedded in a DTV broadcasting stream, which prevents digital television reception equipment from redistributing broadcast content," regardless of whether the redistribution would have been legitimate or supported, for example, by fair use. ${ }^{234}$

If we apply our two-part test from above, the "broadcast flag" bill appears very likely to violate a core protection of the Free Press Clause. First, there is no question

232 Id. $\$ 3(\mathrm{e})$.

233 See Am. Library Ass'n v. FCC, 406 F.3d 689, 691-92 (D.C. Cir. 2005).

${ }^{234}$ Id. at 691; Digital Broad. Content Prot., 18 F.C.C.R. 23,550 (2003) (codified at 47 C.F.R. pts. 73, 76). 
the "broadcast flag" bill regulates speech technologies (e.g., digital television, computers, software, and every "digital media device") that are protected by the Free Press Clause. Indeed, the scope of the broadcast flag bill is absolutely breathtaking: it regulates virtually all digital-content technologies known to humankind. Second, although a final determination of the bill's constitutionality cannot be made until the particular "broadcast flag" rule is specified, the whole idea of banning all digital technologies that do not include measures prescribed by the copyright industries raises a huge constitutional red flag. The Framers would have been profoundly skeptical of Congress adopting bans on speech technologies (such as unauthorized presses or, here, unauthorized digital technologies) to serve copyright holders' interests, for that kind of technology restriction is precisely what led to all the abuses under the British Crown, an experience eventually prompting the Framers to recognize the freedom of the press in the Bill of Rights. ${ }^{235}$

\section{The DMCA Anti-circumvention Provision}

The DMCA provides a final example to consider. ${ }^{236}$ Enacted in 1998, the DMCA anti-circumvention provision is a very complicated set of laws that provide legal protections for copyright holders' efforts to deploy technologies, such as digital rights management (DRM), on their copyrighted works, in order to reduce the amount of copyright infringement of their works, especially through digital technologies. ${ }^{237}$ Given the complexity of the DMCA, a brief summary of the key aspects of the law is necessary. ${ }^{238}$

The DMCA makes it illegal (i) to circumvent access- and copying-control measures (i.e., DRM), such as encryption, placed by copyright holders on their works, and (ii) to make or traffic in circumventing technologies that facilitate the circumvention of such copyright control measures. ${ }^{239}$ In the so-called "no mandate" section,

${ }^{235}$ See Lee, supra note 53, at 321-25.

23617 U.S.C. \& 1201 (2006).

237 Id.

${ }^{238}$ I focus on the main part of the DMCA's anti-circumvention provision in § 1201(a) and (b); these two subsections have generated the most controversy. The DMCA contains another interesting subsection, $\S 1201(\mathrm{k})$, which is often overlooked, but which requires that analog VCR and video devices use the "automatic gain control copy control technology" and the "four-line colorstripe copy control technology." Id. § 1201(k). The technology-mandate provision, however, is mollified because it also bars entities from using these two copy controls (developed by Macrovision) to stop consumer copying of TV shows on VCRs, except in very limited circumstances, such as pay-per-view or video-on-demand. See id. $\S 1201(\mathrm{k})(2)$; Bruce G. Joseph, Copyright Issues on the Internet, the DMCA and Technological Protection Measures, 830 PLI/PAT 483, 512 (2005). Whether or not this technology mandate violates the Free Press Clause, I leave for future inquiry. Because the VHS has been eclipsed by DVDs and DVRs, the examination of this legal issue has become, like the VHS, somewhat obsolete.

23917 U.S.C. § 1201. 
the DMCA makes clear that it does not mandate technology companies to adopt any technological designs or copyright control measures. ${ }^{240}$

There are a host of narrow exemptions for reverse engineering, security testing, law enforcement, and other defined purposes, and an administrative rule-making process before the Librarian of Congress (upon recommendation of the Register of Copyrights) by which interested parties may seek to obtain a three-year exemption from the basic proscription against the act of circumvention, in order to make legitimate, noninfringing uses of a class of copyrighted works. ${ }^{241}$

The DMCA anti-circumvention provision also states, "Nothing in this section shall affect rights, remedies, limitations, or defenses to copyright infringement, including fair use, under this title."242 The Second Circuit, however, has rejected the argument that people can circumvent DRM in order to make a fair use; in the court's view, there is no "fair use" for circumventing access-controls protected by the DMCA. ${ }^{243}$

The DMCA also recognizes, "Nothing in this section shall enlarge or diminish any rights of free speech or the press for activities using consumer electronics, telecommunications, or computing products."244 But the Second Circuit has read this provision, too, as being merely "precatory" and imposing no limitation on the rest of the DMCA anti-circumvention provision. ${ }^{245}$

Courts in three different cases have considered First Amendment challenges to the DMCA's anti-circumvention provision; all have concluded that the law is constitutional based on an intermediate level of First Amendment scrutiny. ${ }^{246}$ None of these cases involved a challenge specifically under the Free Press Clause. ${ }^{247}$ All were decided as First Amendment challenges to the DMCA's restriction on the computer code contained in a circumventing software program, and its related burden on the ability of people to make a fair or other legitimate use of a copyrighted work that is protected by DRM, which cannot be legally circumvented under the DMCA. ${ }^{248}$

If we apply our framework to the DMCA, the anti-circumvention law does not appear to offend a core protection of the Free Press Clause. Therefore, whether it offends some other protection of the Clause is more appropriate for intermediate

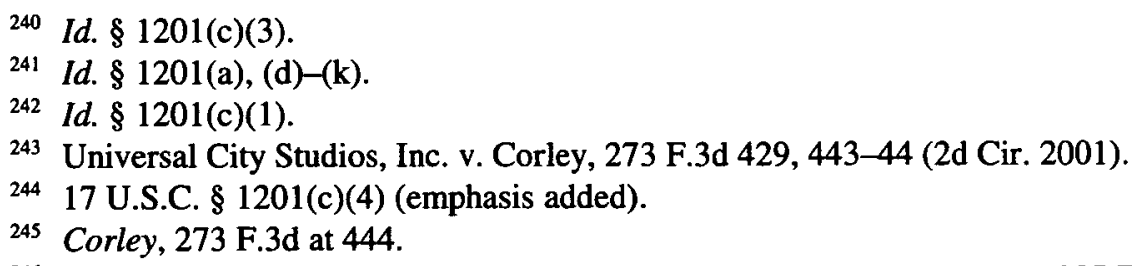

${ }^{246}$ See id. at 449-59; 321 Studios v. Metro Goldwyn Mayer Studios, Inc., 307 F. Supp. 2d 1085 (N.D. Cal. 2004); United States v. Elcom Ltd., 203 F. Supp. 2d 1111, 1128-37 (N.D. Cal. 2002).

${ }^{247}$ Corley, 273 F.3d at 455-59; 321 Studios, 307 F. Supp. 2d at 1099; Elcom, 203 F. Supp. $2 \mathrm{~d}$ at 1122.

${ }^{248}$ See Corley, 273 F.3d at 453-59; 321 Studios, 307 F. Supp. 2d at 1099-1100; Elcom, 203 F. Supp. 2d at $1125-26$. 
scrutiny and consideration of the governmental interests served by the restriction and whether the restriction is narrowly tailored (an inquiry I do not undertake here).

First, it is debatable whether circumventing technologies fall within the kind of speech technologies at the core protection of the Free Press Clause. On the one hand, circumventing technologies typically do not themselves publish, copy, or disseminate speech for people to enjoy. Instead, circumventing technologies are often used to unlock the technological protection, such as encryption, placed on copyrighted works. On the other hand, circumventing technologies can be used as a secondary tool to help facilitate free speech activities, such as legitimate copying and dissemination of a work that is encrypted with DRM (e.g., a movie on a DVD). Yet circumventing technologies (i.e., the specific features that enable circumvention) are not typically the instruments themselves for publishing or copying as the printing press itself was. ${ }^{249}$

Second, even assuming that circumventing technologies do fall within the Free Press Clause's protection, it is not clear whether banning such circumventing technologies violates a core protection of the Clause. The ban on circumventing technologies does not necessarily take away from the public any technologies that themselves produce or disseminate speech. The clearest historical abuse in England involved the government ban on unapproved presses, the machines of mass publication. However, in the case of the DMCA's ban on circumventing technologies-i.e., technologies that unlock the encryption locks on copyrighted works, no machine of mass publication is itself banned. For example, people can still use their computers and the Internet, the technologies by which circumventing technologies are often utilized, to copy and publish many different things. True, the copy function of a computer may be rendered effectively inoperable (to the extent the computer does not have access to the underlying work in a way that allows copying) for an encrypted work, such as a DVD movie, even curbing legitimate fair uses of the work. But the general functionality of computers to copy material still exists, and the DMCA does not require computer manufacturers or other technology developers to adopt copyright control measures in their speech technologies.

Unlike AHRA's direct restriction on digital recorders, or the broadcast flag's direct restriction on digital media devices, the DMCA's restriction on circumventing technologies is arguably one step removed from speech technologies that themselves produce or disseminate speech. Consequently, it is difficult to find a historical analogue for this context. ${ }^{250}$ One might analogize encryption to a kind of special ink

${ }^{249}$ One could imagine a circumventing technology that came equipped with extra functions for publishing and copying. In such case, the circumventing features would still present a circumstance different from the acts of printing or copying analogous to the printing press.

${ }^{250}$ By contrast, to the extent the proposed broadcast flag would regulate the Internet, the Internet functions very much like the printing press in enabling mass publication. See generally Reno v. ACLU, 521 U.S. 844, 853 (1997) ("From the publishers' point of view, [the Internet] constitutes a vast platform from which to address and hear from a worldwide audience of 
used by copyright holders in the printing press; the ink can prevent the printed material from being copied by others, say, on a copy machine (if one existed back then). If someone had developed a way to circumvent the special ink and make copies of printed materials without authorization of the copyright holder, the invention (call it a "special ink decrypter") would be a circumventing technology similar to the ones banned by the DMCA. Would the Framers or Framing generation have considered a ban on the special ink decrypter in the same way as a ban on unapproved printing presses?

Hard to say. This contrary-to-fact hypothetical-not to mention, anachronismpresents a scenario that strains historical comparisons. Consequently, I think the issue is better analyzed under the well-established test of First Amendment scrutiny, as the courts have done so far, which can take into account a balancing of interests. ${ }^{251}$

\section{Summary}

It bears repeating that I am not suggesting that the First and Second Amendment should be treated exactly the same. That would be foolish. However, for too long, courts have avoided exploring the history of the Free Press Clause and grappling with its meaning in First Amendment cases. The Free Press Clause is not a dead letter, but it does remain like a long lost cousin to the more often discussed Free Speech Clause. Just as the Second Amendment stood pre-Heller, the Free Press Clause stands today largely unexamined. This predicament will become increasingly untenable as Congress considers imposing direct restrictions on speech technologies through or in service of copyright law. If such a restriction is challenged one day, as I believe is likely, Heller provides a useful approach for the Court to consider in examining the Free Press Clause head-on.

\section{CONCLUSION}

This Article has examined the Supreme Court's landmark Second Amendment ruling in Heller and its possible effect on future cases brought under the Free Press Clause. Based on the text and history of the Constitution, the connection between the two Clauses is undeniable, as the Heller Court itself repeatedly suggested. Only two provisions in the entire Constitution protect individual rights to a technology: the Second Amendment's right to bear "arms" and the Free Press Clause's right to the freedom of the "press," meaning the printing press. Both rights were viewed as

millions of readers, viewers, researchers, and buyers. Any person or organization with a computer connected to the Internet can 'publish' information.").

${ }^{251}$ It goes beyond the scope of this Article to analyze the DMCA under intermediate First Amendment scrutiny or the respective decisions of the courts thus far. My inquiry focuses on the core protection of the Free Press Clause. 
pre-existing, natural rights to the Framing generation and were each separately called the "palladium of liberty" during the Framing. Both rights developed in reaction to the Crown's abuses in restricting the respective technology in England during the seventeenth century. Given this historical and textual connection, courts should consider applying an approach similar to the one in Heller in interpreting the Free Press Clause. Just as Heller held that banning handguns for the purpose of gun control violates the Second Amendment's core protection of an individual's right to possess arms for self-defense, Congress's bans on speech technologies for the purpose of copyright control may well violate the Free Press Clause's core protection of technologies for self-expression. 